\title{
MiLLI MÜCADELE DÖNEMI MITINGLERINDE TÜRK KADINI*
}

\section{TURKISH WOMEN IN RALLIES DURING THE NATIONAL STRUGGLE NURAY ÖZDEMIR**}

ÖZDEMiR, Nuray, (2021), “Milli Mücadele Dönemi Mitinglerinde Türk Kadıı”, Belgi Dergisi, S.21, Pamukkale Üniversitesi Atatürk İlkeleri ve İnkılâp Tarihi Araştırma ve Uygulama Merkezi Yayını, Kış 2021/I, ss. 1-22

\section{Öz}

Mondros Mütarekesi sonrası yaşanan işgaller ülke genelinde tepkiyle karşılanmış mitingler düzenlenerek protesto edilmiştir. Başta İzmir'in 15 Mayıs 1919'da Yunanlılar tarafindan işgali bu mitinglerin düzenlenmesinde itici rol oynamış ve yapılan toplantılara kadınların ilgisi büyük olmuştur. Kadınlar ilk defa binlerce kişinin katıldığı açık hava mitinglerinde erkeklerle birlikte yer ve söz alıp etkili konuşmalar yapmışlardır. Başta İstanbul olmak üzere kadın-erkek binlerce kişinin katılımıyla yapılan mitinglerin yurt geneline yayılmasında Mustafa Kemal Paşa'nın 28 Mayıs 1919 tarihli Havza Genelgesi'nin de etkisi büyük olmuştur.

İstanbul'da İzmir'in işgalini protesto için ilk miting 19 Mayıs 1919 tarihinde Fatih meydanında yapılmıştır. 20 Mayıs'ta Üsküdar, 22 Mayıs'ta Kadıköy ve 23 Mayıs'ta Sultanahmet Mitingleri düzenlenmiştir. İtilaf Devletleri'nin denetimini giderek artırdığı İstanbul'da yapılan son miting ise 13 Ocak 1920'deki Sultanahmet Mitingi olmuştur. Bu mitinglerde Mehmet Emin (Yurdakul), Hamdullah Suphi (Tanrı̈ver) gibi dönemin öne çıkan isimleri kürsüleri, aydın, şair, öğretmen kimliğiyle tanınan Halide Edip (Adıvar), Nakiye (Elgün), Sabahat (Filmer), Şükufe Nihal (Başar), Hayriye Melek (Hunç) hanımlarla paylaşmışlardır. Kadınlar işgalleri kınayan konuşmalar yaparken ülkenin kurtuluşu için erkeklerle birlikte mücadeleye hazır olduklarını da dünyaya duyurmuşlardır. Sadece İstanbul'da değil Anadolu’nun çeşitli şehirlerinde de kadınların ön planda olduğu mitingler düzenlenmiştir. Bu mitinglere dinleyici olarak kadınların katılımı yoğun olurken kadın konuşmacılara söz verilmemiştir. Ancak Muğla, Ankara, Sivas, Kastamonu, Konya gibi şehirlerde sadece kadınların katıldığı mitingler yapılmış işgalleri protesto eden kararlar alınmıştır. İşgaller karşısında duyulan üzüntü vurgulanarak hak, adalet, Türklük, Müslümanlık için mücadele edileceği duyurulmuştur. Mitingler halk arasında millî birlik ve beraberlik ruhunu güçlendirirken millî mücadele fikrinin geniş kitlelerce benimsenmesinde önemli rol oynamıştır. Bu çalışmada; Milî̂ Mücadele döneminde yapılan protesto mitinglerinde konuşmalarıyla öne çıkan kadınlar ve bunların kitleler üzerinde bıraktığı etkiler incelenmiştir.

Anahtar Kelimler: Millî Mücadele, Miting, Protesto, Kadın, İstanbul.

*Bu çalışma11-14 Haziran 2019 tarihinde Türk Tarih Kurumu ve 19 Mayıs Üniversitesi'nin katkılarıyla Samsun'da düzenlenen 100.Yılında 19 Mayıs ve Milî̃ Mücadele Sempozyumu'nda sunulan bildiriden genişletilerek üretilmiştir.

** Doç. Dr. Abant İzzet Baysal Üniversitesi, Fen Edebiyat Fakültesi Tarih Bölümü, Bolu, ozdemir_n@ibu.edu.tr, (https://orcid.org/0000-0003-0001-6427) 


\begin{abstract}
Occupations following the Armistice of Mudros were reacted against and protested through nationwide demonstrations. Especially the occupation of Izmir by Greeks in May 15, 1919 became an initiator in these demonstrations and there was a huge interest among women in the meetings. For the first time women co-participated with men in open-air demonstrations where thousands joined and they got the floor and gave impressive speeches. Havza Circular (May 28,1919) by Mustafa Kemal Pasha had a great role in thrilling nationwide propagation of the demonstrations that were held with thousands of men and women particularly in İstanbul.

The first demonstration in İstanbul against the occupation of İzmir was held in Fatih square in May 19, 1919. It was followed by demonstrations in Üsküdar in May 20, in Kadıköy in May 22, and in Sultanahmet in May 23. The last one to be held in İstanbul, the city under growing control of the Allied Powers, was in Sultanahmet in January 13, 1920. In these demonstrations prominent people of the period like Mehmet Emin (Yurdakul), Hamdullah Suphi (Tanröver), shared the floor with the ladies Halide Edip (Adıvar), Nakiye (Elgün), Sabahat (Filmer), Şükufe Nihal (Başar), Hayriye Melek (Hunç) known with their intellectual, poet and teacher titles. As the women were giving speeches condemning the occupations, they announced the world that they were ready to struggle for the nation together with men. Not only in İstanbul but also in various cities of Anatolia were the demonstrations in which women were at the forefront were held. While women participation was high in these demonstrations no women was there to address. But in cities like Muğla, Ankara, Sivas, Kastamonu, and Konya only-women demonstrations were held and decisions protesting the occupations were taken. Underlining the sorrow as a result of the occupations, a struggle was announced in pursuit of right, justice, Turkishness and Muslimism. The demonstrations strengthened national unity and solidarity among people, as well as playing key role in the idea of national struggle being adopted by masses. In this work those prominent women speakers in protesting demonstrations during the National Struggle period and their effects on masses are analysed.
\end{abstract}

Keywords: National Struggle, Rally, Protest, Women, Istanbul. 


\section{GiRiş}

Osmanlı Devleti'nde kadınların toplantı yapıp kürsülerde konuşması Müdafaa-ı Milliye Osmanlı Hanımlar Heyeti'nin Balkan Savaşları'nın yol açtığı acılar karşısında Darülfünun Konferans salonunda yaptığı toplantılarla başlamıştır. Yaklaşık dört-beş bin kişinin katıldığı ilk toplantı 8 Şubat 1913'te, ikinci toplantı ise 15 Şubat 1913 tarihinde yapılmıştır. İnas İdadisi gibi dönemin kız okulları öğretmen ve öğrencilerinin büyük ilgi gösterdiği toplantılarda Halide Edip, Fatma Aliye, Nigar Binti Osman, Naciye Hanım, Fehime Nüzhet, Nakiye Hanım gibi aydın, şair, öğretmen, öğrenci kimliği ile öne çıkan kadınlar kürsüye çıkıp kadınları bilinçlendirmeye yönelik heyecanlı konuşmalar yapmışlardır. ${ }^{1}$ Bu toplantıların sonunda ordunun ihtiyaçları için kadınlar kendi aralarında kampanya düzenleyerek önemli miktarda yardım da toplamışlardır. Toplantıya katılan kadınlar para, altın, mücevher gibi değerli eşyalarını vermişlerdir. ${ }^{2}$ Hatta hanımların gözündeki gözlüğü, üzerindeki kürkü dahi çıkarıp verecek derecede fedakârlıkta bulunduklarına dair haberler dönemin basınında öne çıkartılmıştır. ${ }^{3}$ Darülfünun Konferans Salonu'nda kadınlar yaptıkları konuşmalarda erkekleri ülkeyi savunmaya çağırmışlar, Rumeli'den sonra sıranın Anadolu'ya geleceğine değinerek tehlikenin büyüklüğüne dikkat çekmişlerdir. Nitekim 30 Ekim 1918 tarihli Mondros Mütarekesi sonrasında yaşanan işgaller kadınların bu konudaki haklııklarını açık bir şekilde göstermiştir.

I.Dünya Savaşı kadınların sosyal ve iktisadi hayatta daha etkin bir şekilde yer almasına yol açmış Osmanlı kadını öğretmenlikten memurluğa, ticaretten fabrikalara, yol yapımından sokak temizliğine kadar değişik iş alanlarında kendini göstermeye başlamıştır. Birçok iş alanında erkek işgücü açı̆̆ı nedeniyle kadınlar çok hızlı bir şekilde çalışma hayatı içinde yer almışlardır. ${ }^{4}$ Savaş yıllarında kadın cemiyetlerinin faaliyetlerinde de büyük artış yaşanmış özellikle Hilal-i Ahmer Cemiyeti Hanımlar Şubesi, Osmanlı Kadınlar Cemiyeti ve İstihlak-ı Milli Kadınlar Cemiyeti ordunun ihtiyaçlarını karşılamaya yönelik yardım çalışmalarıyla öne çıkan kadın örgütleri olmuşlardır. ${ }^{5}$ Savaş yıllarında daha çok kadınlar mağdur olmakla birlikte kadınların görev ve sorumlulukları da o nispette artmıştır. Seferberliğin getirdiği yükümlülükleri büyük ölçüde kadınlar yerine getirmek zorunda kalmışlardır. Bir taraftan cepheye gidecek askeri desteklerken bir taraftan da cephe için çalışmışlardır. Yaralı askerlere sağlık hizmeti veya giyim ve diğer maddi yardımlar kadınların faaliyetleri sonucunda sağlanabilmiştir. Türk kadını savaş yıllarında fedakarlığın sembolü olmuş özellikle kadınların yürüttüğü faaliyetlere dönemin basınında sıklıkla yer verilmiştir. Türkçülük ekseninde toplumun vatanseverlik duygularını mobilize etmede kadına yönelik propaganda yapılmıştır. Bu propaganda milli kimliğin oluşmasında etkili olduğu gibi kadınların bir amaç doğrultusunda harekete geçmelerini de sağlamıştır. ${ }^{6}$

I.Dünya Savaşı ile kadının statüsünde büyük bir değişim yaşanırken bundan sonra kadınlar ülke sorunları ile daha çok ilgilenmeye başlamışlardır. Mondros Mütarekesi sonrasında başlayan işgallere en sert tepkiler savaş yıllarında milliyetçi ve vatansever kimliği şekillenmeye başlayan Türk kadınından gelmiştir. Özellikle 15 Mayıs 1919 tarihinde İzmir'in Yunanlılar tarafından işgali büyük bir üzüntüye yol açmış işgali protesto etmek için

1 Darülfünun Konferans Salonunda Kadınlarımızın Içtimaları, Tanin Matbaası, İstanbul 1912; Şefika Kurnaz, Balkan Savaşında Kadınlarımız, Ötüken Neşriyat, İstanbul 2012, s.32.

2 "Osmanlı Hanımlarının Muazzam İçtimaı", Tanin, 9 Şubat 1913, s.2.

3 "Hanımlarımızı Nümayiş-i Vatanperveranesi", Tanin, 16 Şubat 1913, s.4.

4 Zafer Toprak, Türkiye'de Yeni Hayat Inkılap ve Travma (1908-1928), Doğan Kitap, İstanbul 2017, s.52.

5 Serpil Çakır, Osmanlı Kadın Hareketi, Metis Yayınları, İstanbul 2011, s.102.

6 Feyza Kurnaz Şahin, “Mağdur ve Sembol: I. Dünya Savaşı Yıllarında Osmanlı Devleti'nde Kadına Yönelik Propaganda, Selçuk Üniversitesi Türkiyat Araştırmaları Dergisi, Güz 2008(44), s.238. 
düzenlenen mitinglerde kadınlar ön planda yer almışlardır. İstanbul'un çeşitli semtlerinde açık havada yapılan mitinglerde ilk defa kadınlar kürsüye çıkıp etkili konuşmalar yapmışlardır. Mitinglerin düzenlenmesine Türk Ocakları, Milli Kongre Cemiyeti, Müdafaa-ı Hukuk Cemiyetleri, Darülfünun hocaları ve öğrencileri öncülük etmiştir. Ayrıca Asri Kadınlar Cemiyeti, Anadolu Kadınları Müdafaa-ı Vatan Cemiyeti gibi kadın örgütleri ile kız okulları öğretmen ve öğrencileri tarafından da desteklenmiştir.

Sadece İstanbul'da değil Anadolu'nun hemen hemen her şehrinde büyük meydanlarda kadın-erkek binlerce kişinin katıldığı sokak mitingleri yapılmıştır. ${ }^{7} \mathrm{Bu}$ mitinglere dinleyici olarak kadınların katılımı yoğun olurken kadın konuşmacılara söz verilmemiştir. Ancak Muğla, Ankara, Sivas, Edirne, Kastamonu, Konya gibi şehirlerde sadece kadınların katıldığı mitingler yapılmış işgalleri protesto eden kararlar alınmıştır. Bu mitinglerde konuşanların çoğu kadın öğretmenler olup aralarında İnas Darülfünunu öğrencileri ile bazı cemiyetlerde çalışan kadınlar da bulunmaktadır. Özellikle Halide Edip Adıvar milli duyguları hareke geçiren konuşmalarıyla milli mücadele mitinglerinin sembol ismi olmuştur. ${ }^{8}$ Kadınlar yaptıkları heyecanlı konuşmalar ile İtilaf Devletlerinin haksız ve yersiz işgallerine karşı halkı bilgilendirmiş ve vatan savunması için çağrıda bulunmuşlardır. ${ }^{9}$

Mitinglerin büyük bir heyecan içinde yurt geneline yayılmasında 19 Mayıs 1919'da Samsun'a çıkan Mustafa Kemal Paşa'nın 28 Mayıs 1919 tarihli Havza Genelgesi'nin de etkisi büyük olmuştur. Mustafa Kemal Paşa Havza'dan ülkedeki askeri ve mülki amirlerle Müdafaa-ı Hukuk Cemiyetlerine çektiği telgrafla Anadolu'da yaşanan haksız işgallerin protesto edilmesi için yurdun her tarafında mitingler düzenlenmesini ve İtilaf Devletleri temsilcilerine protesto telgrafları gönderilmesini istemiştir. Bu genelge üzerine mitinglerin ve protesto telgraflarının sayısı gün geçtikçe artmıştır. ${ }^{10}$ Kuva-yı Milliye ruhunun ortaya çıkmasında, millî mücadele fikrinin gelişmesinde ve kamuoyu oluşturmada mitinglerin rolü çok büyük olmuştur.

Bu çalışmada, Milî̂ Mücadele döneminde yapılan protesto mitinglerinde kadınların yaptığı konuşmalar incelenmiştir. Mitinglerde kadın hatiplerin yaptığı konuşmalardan kesitler verilerek işgaller karşısında Türk kadınının sergilediği duruş üzerinde durulmuştur. Konuşmaların metinleri İkdam, Tanin, Tasvir-i Efkâr, Vakit gibi gazetelerden alınmıştır. Ancak miting haberlerine yer yer sansür uygulandığından bazı konuşmaların tam metnine ulaşılamamıştır. Kadınlar miting kürsülerinde milliyetçi bir söylemle işgallere karşı tepkilerini sert bir şekilde göstermişlerdir. Kadınların milli duygulara hitap eden bu konuşmaları halkın vatanseverlik duygularını kabartmıştır. Dönemin gazeteleri de kadınların yaptığı konuşmaları ön plana çıkartarak miting haberleri üzerinden işgaller karşısında direnişe geçmeye ve askerliği özendirip cepheye katılmaya yönelik propaganda yapmışlardır. Bu bağlamda milli kimlik inşasında ve Kuva-yı Milliye ruhunun geniş halk kitlelerine yayılmasında Millî Mücadele dönemi mitinglerindeki Türk kadının rolü irdelenmeye çalışılımışır.

\footnotetext{
7 Leyla Kaplan, Cemiyetlerde ve Siyasi Teşkilatlarda Türk Kadını (1908-1960), ATAM Yayınları, Ankara 1998, s.77.

8 İnci Engünün vd., Millî Mücadelede Türk Kadını, Ankara 1983, s.14.

9 Hülya Yalçın, Cumhuriyet Dönemi Kadın Imajı Inşası (1928-1938), Hacettepe Üniversitesi Atatürk İlkeleri ve İnkılap Tarihi Enstitü Basılmamış Yüksek Lisans Tezi, Ankara 2019, s.43.

10 Mehmet Şahingöz, "Millî Mücadelede Protesto ve Mitingler", Türkler, C.15, Yeni Türkiye Yayınları, Ankara 2002, s.727.
} 


\section{A-i̇şgaller Karşısında İstanbul Kadınlarının İlk Tepkileri}

Mondros Mütarekesi sonrasında başlayan işgaller karşısında tepkinin gösterildiği, işgal kuvvetlerinin protesto edildiği ilk açık hava toplantısı 19 Mart 1919 tarihinde İnas Darülfünunu ve Asri Kadınlar Cemiyeti ${ }^{11}$ tarafından kadınların katılımıyla Fatih Türbesi'nde yapılmıştır. Aliye Esat ve Naciye Faham hanımların öncülük ettiği bu toplantıya cemiyet üyeleri, İnas Darülfünunu öğrencileri ve halkın katılımı da geniş olmuştur. Törene saat üçte başlanmış ve halkın bir kısmı öncelikle türbe içinde toplanarak Kur'an-ı Kerim tilavet eylemişlerdir. Okunan dualardan sonra Darülfünun Edebiyat Fakültesi'nden bir öğrenci tarafından Abdülhak Hamit (Tarhan) Bey'in "Türbe-i Fatihi Ziyaret" manzumesi okunmuştur. ${ }^{12}$ Ardından Darülfünun mezunlarından Mediha Muzaffer Hanım İstanbul'un Türklerde kalacağına dair bir açıklama yapmış ve dönemin basınına yansıdığı şekliyle "vatansever bir tezahüratta" bulunmuştur. Toplantıya katılan kadınların coşkulu hislerine tercüman olmuş ve onun öncülüğünde "İstanbul'dan gitmeyiz! Gitmeyiz! Gitmeyiz" sözlerini toplantıya katılan bütün hanımlar hep bir ağızdan tekrarlamışlardır. ${ }^{13}$

Daha sonra Asri Kadınlar Cemiyeti adına Naciye Faham Hanım söz almıştır. Ülkenin içinde bulunduğu zor koşulları anlatarak konuşmasına şu şekilde son vermiştir: "Milletin fikrini milletin kuvvetini zerre kadar kale almadan ve ona muhalif olarak hareket eden harp kabinesi bir sebeb-i siyasi ve idari ve belki de bir sebeb-i askeri uğrunda Ermenilerden bazılarını nakil bazılarını da tehcire lüzum görmüşlerse bundan bütün millet niçin mesul olsun?"14 Savaş yıllarında İttihat ve Terakki Partisi'nin izlediği politikalardan dolayı bir milletin cezalandırılamayacağını ifade etmiştir.

İstanbul'da ülkenin içinde bulunduğu belirsizlik ve işgal tehlikelerine karşı kıpırdanmaya başlayan tepkileri 15 Mayıs 1919'da Yunanistan'ın İzmir'i işgali iyice tetiklemiştir. Kadınerkek İstanbul halkı 16 Mayıs tarihinden itibaren tepkisini her ortamda göstermeye başlamıştır. İzmir'in işgaline yas tutan İstanbul kadınları sinema, tiyatro gibi eğlence yerlerine gitmeme kararı almışlardır. Okullar ve işyerleri de kısa süreli kapatılmıştır. ${ }^{15}$

İzmir'in işgali karşısında üniversite öğrencileri de 18 Mayıs 1919'da Darülfünun'da Besim Ömer Paşa başkanlığında bir toplantı düzenlemişlerdir. Dersler boykot edilmiş müderris ve öğrencilerden yoğun katılımın olduğu toplantıda kürsüde konuşma yapmak üzere her fakülteden temsilciler seçilmiştir. Hukuk Fakültesi'nden Muslihiddin Adil Bey ile Tıp Fakültesi'nden Akil Muhtar Bey'in konuşmasından sonra Rıza Tevfik Bey'in kürsüye çıktığı toplantıda dönemin kaynaklarında ismi belirtilmediği için kim olduğunu tespit edemediğimiz İnas Darülfünundan bir hanım da söz almıştır. Konuşma Tasvir-i Efkâr Gazetesi'nde şu şekilde yer almıştır: "Türk Gençliğinin nısfını biz teşkil ediyoruz. Biz de aynı fikirdeyiz. Türk gençliği her daim kadınlığı, münevver kadınlığı yanında görecektir. Buna emin olunuz. İcap ederse gençlik yanında ve vatan uğruna biz de öleceğiz."16 Konuşmasında kadınların da erkeklerle beraber mücadeleye hazır olduğunu belirterek

\footnotetext{
11 Asri Kadınlar Cemiyeti 1918 yılında İstanbul'da İnas Darülfünunu mezunları ve öğrencileri tarafından kurulmuş ve "kadınların bedenen, fikren terbiyesine çalışarak içtimaen mevkiini yükseltmeyi" amaçlamıştır. Türkiye Cumhuriyeti Cumhurbaşkanlığı Devlet Arşivi Başkanlığı Osmanlı Arşivi (BOA), DH.EUM.5.Şb/79-30; “Asri Kadın Cemiyeti", İnci, 1 Şubat 1919, Sayı:1, s.2; Çakır, a.g.e., s.87-103.

Kaplan, a.g.e., s.72.

12 "Istanbul Türk Kalacaktır”, ikdam, 20 Mart 1919, s.2.

13 “Ulvi Bir Tezahür”, Genç Kadın, 27 Mart 1919, Sayı:7, s.108; “Fatih Cami-i Şerifinde”, Hadisat, 20 Mart 1919, s.1.

14 “istanbul Türk Kalacaktır”, ikdam, 20 Mart 1919, s.2.

15 “izmir Hadisesinin İstanbul Vilayetindeki Tesiratı”, İkdam, “19 Mayıs 1919, s.1.

16 “Darülfünun'da İçtima ve Tezahüratın Devamı”, Tasvir-i Efkâr, 19 Mayıs 1919, s.1.
} 
sözlerini şöyle sonlandırmıştır: "Teşebbüsatınıza en kavi bir imanla iştirak ediyor ve şu hakikati isma etmek (duyurmak) istiyoruz: Kim demiş bir kadın küçük şeydir, Bir kadın belki en büyük şeydir." Toplantı sonunda İstanbul'un muhtelif semtlerindeki meydanlarda protesto mitingleri yapılması kararlaştırılmıştır. ${ }^{17}$ Mitinglerin düzenlenmesine Türk Ocağı öncülük yapmış Halide Edip Adıvar, Hamdullah Suphi Tanrı̈ver, Mehmet Emin Yurdakul, Dr.Sabit Bey gibi Türk Ocağı'nın önde gelen isimleri miting kürsülerinden etkili konuşmalar yapmışlardır. ${ }^{18}$ Darülfünun öğrencileri de mitinglerin organizasyonunda önemli görevler üstlenmişlerdir. Gençliği temsilen kürsüye çıkan Meliha Hanım gibi Darülfünun öğrencileri halka direniş için çağrıda bulunmuşlardır. ${ }^{19}$

\section{B-Fatih'te Yapılan İlk Açık Hava Mitinginde Kadınlar}

İzmir'in işgalini protesto için İstanbul'da ilk açık hava mitingi 19 Mayıs 1919 tarihinde Fatih Belediye Dairesi önünde yapılmıştır. Bu mitingin düzenlenmesi Türk Ocağı'nda yapılan bir toplantıda kararlaştırılmış ve öğrenci birlikleri de desteklemiştir. Miting günü İstanbul esnaf ve tüccarı dükkânlarını, mağazalarını kapatmıştır. Bütün okullar, müesseseler tatil edilmiş ve Fatih parkında genç-yaşlı, kadın-erkek İstanbul halkının katılımıyla büyük bir miting düzenlemiştir. Belediye dairesinin balkonun iki tarafında siyah zemin üzerine beyaz ay yıldızlı birer bayrak çekilmiştir. ${ }^{20}$ Mitinge katılım oldukça fazla olmakla birlikte dönemin basınında katılımcı sayısına dair farklı rakamlar yazılmıştır. İkdam Gazetesi'nde on binden fazla olduğu bilgisi verilirken, Vakit Gazetesi'nde ise elli bine yakın bir halk topluluğu olduğu haberi yer almıştır. ${ }^{21}$

Yoğun katılımın olduğu mitingin beş konuşmacısından ikisi kadın olup bunlar, aynı zamanda Türk Ocağı üyesi de olan Halide Edip Hanım ve Darülfünun öğrencisi Meliha Hanım'dır. Daha önce birçok kapalı salonda konuşma yapan Halide Edip Hanım ilk kez bir açık hava toplantısında konuşma yapmıştır. Bu Türk kadının miting kürsüsüne ilk çıkışıdır. Ülkenin işgali Türk kadının statüsünde yaşanan değişim sürecinde kadına bir adım daha attırmıştır. ${ }^{22}$

Mitingin ilk konuşmacısı olan Halide Edip Hanım kürsüye çıktığında hissettiği duyguları Türkün Ateşle İmtihanı adlı eserinde şöyle anlatmaktadır:

“Halk, Fatih Belediyesinin önünde toplanmıştı. Balkondan konuşulacaktı. Sesimi kalabalığın hepsine işittirmek mümkün olabilecek mi diye düşünürken dramatik bir olay bana bu endişemi unutturdu. Binanın üzerinde ay-yıldızlı kırmızı bayraklar rüzgârda sallanırken, onun altında da yani balkonun demir parmaklığından aşağıya doğru bir siyah örtü sarkıtılmıştı. Demir parmaklığın siyah örtüsü üzerinde bir insan denizi ile karşı karşıya gibiydim. Kalabalığın ortasında askerler ve subaylar vardı. Onların çevresinde çoğu genç olmak üzere siyah çarşaflı kadınlar bulunuyordu. Hepsi söylevi bekliyordu. Aynı zamanda beyaz sarıklılar, kırmızı fesliler, birkaç tane de şapkalı vardı.

17 “Darülfünununda Heyecanlı Bir İçtima”, Vakit, 19 Mayıs 1919, s.2.; Kemal Arıburnu, Millî Mücadelede İstanbul Mitingleri, Yeni Desen Matbaası, Ankara 1975, s.10.

18 Mehmet Şahingöz, "Millî Mücadelede Yapılan Mitinglerde Türk Ocaklarının Rolü ve Hamdullah Suphi”, Hamdullah Suphi ve Gagauzlar, Türk Yurdu Yayınları, Ankara 2016, s. 34.

19 M. Korkud Aydın, Millî Mücadele Dönemi İstanbul Öğrenci Hareketleri (1918-1922), Fırat Üniversitesi Sosyal Bilimler Enstitüsü Basılmamış Yüksek Lisans Tezi, Elâzığ 2011, s.4-5.

20 "Fatih'te İstanbul Ahalisinin Muazzam Mitingi”, Memleket, 20 Mayıs 1919, s.1.; "Sevgili İzmir İçin İstanbul Müslümanlarının Dünkü Tezahüratı”, i̇kdam, 20 Mayıs 1919, s.1.

21 Sevgili İzmir İçin İstanbul Müslümanlarının Dünkü Tezahürat”, i̇kdam, 20 Mayıs 1919, s.1, “Dün Fatih’te 50 Bin Kadın ve Erkekten Mürekkep Bir Miting Akd Edilmiştir", Vakit, 20 Mayıs 1919, s.1.

22 Zeki Saruhan, Kurtuluş Savaşı Kadınları, Cem Web Ofset, Ankara 2006, s.89. 
Fakat insan kalabalığın karşısında ne olduğunun farkına bile varmıyor. Çünkü parlayan gözler, söyleyeceğini insana ilham ediyordu..."23

Halide Edip Hanım konuşmasına "Müslümanlar, Türkler! Türk ve Müslüman bugün en kara gününü yaşıyor. Gece, karanlık bir gece... Fakat insan hayatında sabahı olmayan gece yoktur. Yarın belki meşaşa (parlak) bir sabah doğacaktır..." sözleriyle başlamıştır. Kadınlara seslenerek büyük bir inançla içinde bulunulan tüm olumsuz koşullara karşı mücadele için çağrıda bulunup ellerindeki gücü şöyle hatırlatmıştır: “...elinizde tüfek top yok Hak var Allah var. (Alkışlar) tüfek ve top düşer, fakat hak ve Allah bakidir. Topun yüzüne tükürecek kadar evlatlar, analar, kalbimizde aşk ve millet duygusu var. Hiç korkmayacaksınız hanımlar, Türkler, Müslümanlar! Silah ile çalışmazsanız Hak ve Allah sizinledir. Dünyada millet sınıfına layık olduğumuzu erkek, kadın hatta ihtiyar ve çocuklarımıza kadar ispat ettik." Halide Edip Hanım konuşmasında Padişaha da seslenerek şunları söylemiştir: "Biz sözümüzü onlara (işgal kuvvetlerini kastetmekte) dinletemeyiz. Sözümüzü padişahımıza dinletebiliriz. Biz şimdi erkeklerimizle beraber milletin kalbinden gelen en kuvvetli en milli en cesur milleti en çok temsil edecek bir kabine isteriz... Padişahımıza halkın hissiyatını tebliğ eder ve deriz ki işte kara bir gün yaşıyoruz. Bugün herkes susmuştur. Bugün Türk ve Müslüman padişahın etrafında toplanmıştır." ${ }^{24}$

Fatih mitingine katılan Darülfünun öğrencisi i. Hakkı Sunata anılarında daha miting hazırıkları yapılırken balkona serilen siyah örtüyü ve asılan siyah bayrakları gören halkın özellikle de kadınların "Ah..Ah... bunu da mı görecektik böyle..." diye ağlamaya başladıklarını kendisinin de bu manzara karşısında gözlerinin yaşardığını aktarmaktadır. Hiçbir konuşma yapılmasa da yalnız bu gösterini bile halkın duyduğu acıyı anlatmaya yettiğini ifade etmektedir. Halide Edip Hanım'ın konuşmasının bıraktığı derin etkiyi ise şöyle anlatmaktadır: “...Gerçekten acıyı içten duyan bir insan olarak oradaki halkın da duygularını dile getirdi. Birçok insan kendini tutamıyor, gözyaşlarını döküyordu. Heyecan ve teessürünü tutamayanlar her türlü fedakarlığı ve ölümü göze alarak çarpışacaklarını acı acı bağıranlar, kaynaşmayı bir kat daha arttırıyor, kadınlar arasında telaş ve endişe uyandırıyordu." 25

Balkan Savaşı yıllarından itibaren Türkçü kimliğiyle tanınan bir yazar olan Halide Edip Hanım'ın ${ }^{26}$ bu konuşması işgaller karşısında mücadele fikrini aşılarken milli kimlik bilinci oluşturmada önemli bir mihenk taşı olmuştur. Adeta milli mücadele dönemi mitingleriyle ismi özdeşleşen Halide Edip Hanım, büyük kalabalıklara yönelik yaptığı heyecanlı konuşmalarla Türk ruhunu yeniden canlandırmak ve milli kimlik inşası için çalışmıştır. Milli duygulara hitap eden konuşmalarla halkın vatanseverlik duygularını kabartmıştır.

Halide Edip Hanım'dan sonra Hukuk Fakültesi müderrislerinden Selahattin Bey, Türk Ocağı Kâtip-i umumisi Hüseyin Ragıp Bey, İhtiyat Zabitanı Teavün Cemiyeti başkanı Tahsin Fazıl ve Doktor Sabit Beyler kürsüye çıkmışlardır. Son olarak ise Darülfünun öğrencisi Meliha Hanım heyecanlı bir konuşma yaparak katılımcıların hislerine şöyle tercüman olmuştur: "İslamlar, bin tarihinden beri müzmin bir hastalığa tutulan sevgili vatanımız yüz seneden beri hali ihtizarda yaşıyordu. Fakat bugün, ey Türk, satvet ve şevket ile yaşayan şark yıldızı sönmek üzeredir. Yedi asırdan beri Payidar olan bu mukaddes binayı devletimiz gözlerimizin önünde yavaş yavaş çöktürülüyor, fakat bu koca devlet yıkılırken öyle bir

23 Halide Edip Adıvar, Türkün Ateşle Imtihanı, Atlas Kitabevi, İstanbul 1992, s.29.

24 “Sevgili İzmir İçin İstanbul Müslümanlarının Dünkü Tezahüratı”, İkdam, 20 Mayıs 1919, s.1.

25 i. Hakkı Sunata, İstanbul'da İşgal Yılları, Türkiye İş Bankası Yayınları, İstanbul 2019, s.35.

26 Erol Köroğlu'na göre Halide Edip Hanım bir Türk milliyetçisidir. Bkz: Erol Köroğlu, Türk Edebiyatı ve Birinci Dünya Savaşı (1914-1918) Propagandandan Milli Kimlik Inşasına, İletişim Yayınları, İstanbul 2004, s.354. 
tarraka ile devrilmeli, öyle bir çatırtı ile devrilmelidir ki o binanın çatısı cihanı sarsmalı, bütün insaniyeti titremelidir..." Meliha Hanım, ülkenin içine düştüğü durumdan kurtulmak için mücadele etme gereği üzerinde durarak halkı mücadeleye çağırmıştır. Konuşmasını hak ve adalete vurgu yapan şu sözlerle sonlandırmıştır: "Vatanımızı kurtarmak için yaşayacağız kuvvetle iman ediyoruz ki büyük Allah'ımıza sığınarak, cebir ile alınan bir hak elbette iade edilecektir. ${ }^{27}$

Fatih mitingi büyük bir halk gösterisine dönüşmüş ve miting sonrasında Darülfünun'da toplanan miting heyeti birtakım kararlar almıştır. Padişaha ülkenin durumunu arz etmek üzere Halide Edip Hanım ve iki gencin Saraya gönderilmesi uygun görülmüştür. Ancak Padişah heyeti kabul etmemiş miting kararları yaveri vasıtasıyla iletilmiştir. Ayrıca ABD Başkanı Wilson'a Türkiye'nin işgalini protesto eden bir de telgraf çekilmesine karar verilmiştir. ${ }^{28}$

\section{C-Üsküdar Doğancılar Mitinginde Kadınlar}

İstanbul'da yapılan ikinci miting Fatih Mitingi'nin ertesi günü 20 Mayıs 1919 tarihinde Üsküdar Doğancılar'da yapılmıştır. Kadın, erkek bütün Üsküdar halkı ağlayarak mitinge koşmuş ve yaklaşık 30 bin kişinin katıldığı toplantının sekiz konuşmacısından üçü kadın olmuştur. Bunlar, Asri Kadınlar Cemiyeti adına Sabahat Hanım ve Naciye Faham Hanım ile Üsküdar Sanayi Mektebi Fransızca Öğretmeni Zeliha Hanım'dır. Üsküdarlı şair Talat Bey mitingi açılış konuşmasını yapmış sonrasında Doktor Ferruh Niyazi Bey kürsüye çıkmıştır. Ardında da Asri Kadın Cemiyeti adına Sabahat Hanım tarafından heyecanlı bir konuşma yapılmıştır. ${ }^{29}$ Miting gününe dair Sabahat Hanım anılarında şunları anlatmaktadır: "Doğancılardaki bir mezarlığın demir parmaklıkları önünde toplandık. Gözlerimizin önünde renkli bir halı gibi uzanan büyük bir kalabalık vardı. Coşan halk, güneşe, rüzgâra bakmıyor, durmadan dalgalanıyor, her an biraz daha büyüyordu. Bugünkü konuşmacılar Asri Kadın Cemiyeti'nden iki üniversiteli idi. Naciye Faham ve ben Sabahat Hüsameddin. İkimiz de halkın heyecanı karşısında büyülenmiş gibi idik. Ben sesimde hıçkırıklar, gözümde yaşlar dolu olarak konuştum." ${ }^{30}$

Sabahat Hanım konuşmasına "Ey Muhterem talihsiz ahalimiz!" sözleriyle başlayarak İzmir'in işgalinden duyduğu üzüntüyü şöyle ifade etmiştir: “...Işste hayatı, ruhu Türk olan İzmir'i bugün Yunanlılar aldılar. Belki yarın da sinemizden bir şey, kalbimizden bir hayat koparır gibi birer birer Konya'mızı, Bursa'mızı hatta evet bütün güzellikleriyle nazarları celp eden çok sevgili İstanbul'umuzu da isteyecekler." İzmir'den sonra belki de birer birer Konya'ya, Bursa'ya ve hatta İstanbul'a sıranın geleceğini üzüntü ile açıklamıştır. Bu durumu sakin bir şekilde karşılamayacağız diyerek kadınların en önde mücadele edeceğini ifade etmiştir. ${ }^{31}$ Sabahat Hanım medeniyet adına yalan söyleyen varlıklara lanet ettiğini haykırarak meydanı dolduran halkın duygularına hitap etmiştir. ${ }^{32}$ Sabahat Hanım'ın konuşmasından sonra Üsküdar Sultanisi muallimlerinden Mazhar Bey de heyecanlı bir konuşma yapmış ve mitinge katılanları coşturmuştur. Ardından Asri Kadınlar Cemiyeti üyesi Naciye Faham Hanım ise İzmir'in Türklüğüne dair şunları söylemiştir:

27 Arıburnu, a.g.e., s.18.

28 Kaplan, a.g.e., s.74; Afet İnan, Tarih Boyunca Türk Kadının Hak ve Görevleri, Milli Eğitim Basımevi, İstanbul 1975, s. 105.

29 Sarıhan, a.g.e., s.92; “Dün de Üsküdar'da Büyük Bir Içtima Akd Edildi”, Hadisat, 21 Mayıs 1919, s.1.

30 Sabahat Filmer, Atatürk Yolunda Büyük Adımlar, Gül Matbaası, İstanbul 1983, s.49.

31 "İzmir Hadisesi Milletin Kalbine Kök Saldı", İkdam, 21 Mayıs 1919, s.1.

32 Kaplan, a.g.e., s.75. 
“izmir mülkümüzün tarih hayatından coğrafyasından silinemez. Çünkü onda asılarca yaşayan ferdin hatıraları, Türk abideleri tamamıyla Türk zeybekleri, efeleri var. Ona sahip olmak isteyenler bu canlı abide-i hamaseti hâkimiyetleri altında yaşamazlar. Muhterem kardaşlar! Biz eğer vatanımızın kanlı yaralarına bir insicam ve tesanütle sarılır, onun tedavisine kırılmaz bir azim dönmez bir sebatla koşarsak elinde bütün bu yüksekliklerin maverasında titreyen hak, adalet ve müzahirimiz olacaktır.

Düşününüz efendiler siz bu cidalde yalnız değilsiniz. Arkanızda yanık bağırlarıyla yaşlı kederleriyle koşan yetişen kadınlar analarınız kardaşlarınız evlatlarınız var. Yaşasın bütün millet ve âlem-i İslam. ${ }^{33}$

Naciye Hanım, miting meydanını dolduran kalabalıktan İzmir'in işgaline karşı direniş için çağrıda bulunmuştur. Bu mücadelede erkeklerin yalnız olmadı̆̆ı, arkalarında kadınların olduğunu belirtmiştir. ${ }^{34}$ Döneme hâkim olan milliyetçilik fikrinin ektisiyle konuşmasında Türklük vurgusu öne çıkmıştır.

Son kadın konuşmacı olarak Üsküdar Sanayi Mektebi Fransızca muallimesi Zeliha Hanım kürsüye çıkmıştır. İzmir'in işgali karşısında isyan ettiğini belirterek "İzmir bizimdir bizim kalacaktır. İzmir Türklerin namusu, kanı, canıdır. İzmirsiz, Konyasız, İstanbulsuz Türk yaşayamaz." sözleriyle kalabalığın duygu ve düşüncelerini dile getirmiştir. Konuşmaların ortak noktası vatanseverlik olup miting sonunda Fatih mitinginde alınan kararlar aynen benimsenmiştir. ${ }^{35}$

\section{D-Makriköy (Bakırköy) Kadın Mitingi}

İstanbul'da 20 Mayıs 1919 tarihinde sadece hanımların katıldığı bir miting ise Makriköy'de ${ }^{36}$ yapılmıştır. Yaklaşık dört-beş bin kadının katıldığı mitinge Makriköy kız okullarının öğrencileri de katılmıştır. Mitingi birkaç Fransız subayı da izlemiştir. Adile Sultan Numune Mektebi müdiresi Reşide Hanım, muallime Saadet Hanım, öğrencilerden Vedia ve Seniha hanımlar heyecanlı konuşmalar yapmışlardır. Özellikle Fransız subaylarına hitap ederek şunları söylemişlerdir: "Fransızlar 1870 muharebesinin sonunda nasıl teessür duymuşlarsa biz de bugün aynı teessürü duyuyoruz, Fransızların bize yardım etmelerini talep ederiz". Mitingde kadınları temsilen bir heyet teşkili ve "izmir'i vermemeye azmettiklerini" anlatan bir muhtıranın kaleme alınarak İtilaf Devletleri temsilcilerine verilmesi kararlaştırılmıştır. ${ }^{37}$

\section{E-Kadıköy Mitinginde Kadınlar}

Kadıköy İskele Meydanı'nda 22 Mayıs 1919 tarihinde yapılan mitinge şiddetli yağmura rağmen 20-30 bin kişi katılmıştır. Bu mitingin hazırlıklarında Darülfünun öğrencileri aktif rol oynamış özellikle tıbbiyede okuyan gençler büyük çaba göstermişlerdir. ${ }^{38}$ Fahrettin Hayri Bey'in İzmir'in işgalini protesto eden konuşmasından sonra Hüseyin Suat Bey İzmir'in işgalinden duyulan üzüntüyü anlatan bir şiir okumuştur. Kürsüye daha sonra İnas Darülfünunu öğrencisi Münevver Saime Hanım çıkmıştır. İzmir'in işgalini protesto eden, Türklük şuurunu dile getiren heyecanlı bir nutuk söylemiştir. "Az söylemek, çok iş yapmak

33 "İzmir Hadisesi Milletin Kalbine Kök Saldı", ikdam, 21 Mayıs 1919, s.1.

34 Kemal Arıburnu, Millî Mücadelede İstanbul Mitingleri, Yeni Desen Matbaası, Ankara 1975, s.26.

35 “Üsküdar'da İkinci Büyük Miting”, Vakit, 21 Mayıs 1919, s.1-2.

36 Günümüzde Bakırköy olarak bilinmektedir.

37 “Makriköy'deki Miting”, Vakit, 22 Mayıs 1919, s.2; “Makriköy Hanımlarının Mitingi”, İkdam, 21 Mayıs 1919, s.1.

38 Zekeriya Türkmen, Millî Mücadele Yıllarında İstanbul Mitingleri, Berikan Yayınevi, Ankara 2016, s.105. 
zamanı gelmiştir. Biz yalnız ağıyoruz, ağlamakla kazanılacak, hıçkırıklarımızı işitecek bir kalp yoktur. Teşkilata nihayette fiiliyata başlamak lazımdır." sözleri ile halkı mücadeleye davet etmiştir. Ancak Münevver Saime Hanım'ın konuşması halkı kışkırtıcı bulunmuş ve İtilaf Devletleri tarafından miting sonrasında tutuklanmak istemiştir. Bunun üzerine Münevver Saime Hanım Anadolu'ya kaçmış ve ordu hizmetine girerek çavuş rütbesi ile cephede mücadelesini sürdürmüştür. ${ }^{39}$

Kadıköy mitinginin bir diğer konuşmacısı yazar Hayriye Melek Hanım olmuştur. Konuşmasına "Bugün şu yağmurun altında haksızlığa karşı bağırmak için toplanan bu halk kitlesi çarpan bir kalp, sönmeyen bir iman, yaşayan bir ırktır." sözleriyle başlayarak dinleyicilerden büyük alkış almıştır. Konuşmasında medeni dünyaya seslenerek "... damarlarımızda kan durmadıkça, kalplerimiz çarpmakta devam ettikçe o topraklar bizimdir, bizim kalacaktır." sözleriyle mücadeleden asla vazgeçilmeyeceği mesajını vermiş̧ir. ${ }^{40}$ Konuşmasının sonunda ezan, minare gibi kutsal imgeleri kullandığı cümlelerle halkı coşturmuştur.

Kadıköy mitinginin üçüncü kadın konuşmacısı olan Halide Edip Hanım anılarında miting gününe dair şunları aktarmaktadır: "Fırtınalı ve yağmurlu bir gündü. Fakat bu halkın orada toplanmasına engel olmadı. Ben gene Belediye binasının balkonundan konuştum. Önümde bir şemsiye denizi çalkalanıyordu. Arada bir suların arkasından bazı yüzler de görebiliyordum. Onların arkasından beyaz köpüklü dalgalar durmaksızın akıp gidiyor ve ta uzaklarda ufuklarda mavilik görünüyordu. Fakat yağmur devam etti ve halk üç saate yakın oradan ayrılmadı." ${ }^{41}$

Halide Edip Hanım konuşmasında İzmir'in işgalinden duyduğu üzüntüyü dile getirip hak ve adalete olan inancını şöyle ifade etmiştir: "Dün İstanbul'a gelmek isteyen bir çarlık vardı. O Çarlığın yerlerinde bugün yeller esiyor. Niçin? Biz o çarlığın nefesini Çanakkale'de boğduk. Burada devrilen yalnız çarlık değildir, adaletsizliktir. Bu adaletsizlik muvakattir. Belki de biz adaletin geldiğini göremeyeceğiz. Fakat o gecikmeyecektir. Bütün adaletlerin üstünde bir adalet-i ilahi vardır ki, gelecek ve bütün milletleri sarsarak üzerinden geçecektir." 42 Konuşmasında Avrupalı devletlerin taraflı tutumunu eleştirerek bir gün mutlaka adaletin yerini bulacağına olan inancını geniş halk kitleleriyle paylaşmıştır. ${ }^{43}$

\section{F-Sultan Ahmet Mitinglerinde Kadınlar}

İlk Sultan Ahmet Mitingi 23 Mayıs 1919 Cuma günü düzenlenmiştir. İstanbul'da yapılan mitingler arasında en görkemlisi ve en çok katılımın yaşandığı miting olmuştur. Bu mitingle ilgili dönemin basınında 150-200 bin kişinin katıldığına dikkat çekilmiştir. Elliden fazla cemiyetin, siyasi partinin ve bütün okulların katıldığı bu mitingde hitabet kürsüsüne ve miting alanına siyah bayraklar asılmış bir milli matem gösterisi içinde "iki milyon Türk, iki yüz bin Rum'a feda edilemez", "Türk hürdür, esir olamaz" ve "Hak isteriz" gibi dövizlere yer verilmiştir. Kürsünün üzerine siyah bir çerçeve içerisinde Wilson prensiplerinin on ikinci maddesi yazıımıştır. Milli ve dini bir gösteri yapılmış, minarelerden de tekbir sesleri yükselmiştir. İşyerleri dükkânlar kapatılmış, esnaf, memur, kadın erkek bütün halk katılmıştır. ${ }^{44}$

39 Kaplan, a.g.e., s.76; İnan, a.g.e., s.106; “Kadıköylülerin Dünkü Muazzam Mitingi”, Vakit, 23 Mayıs 1919, s.1.

40 Türkmen, a.g.e., s.112.

41 Adivar, a.g.e., s.31.

42 Arıburnu, a.g.e., s.38.

43 “i̇zmir'in İşgalinin Kalb-i Millette Açtığı Yara...”, İkdam, 23 Mayıs 1919, s.1; “Kadıköylülerin Dünkü Muazzam Mitingi", Vakit, 23 Mayıs 1919, s.1.

44 Arıburnu, a.g.e., s.39; İnan, a.g.e., s.106; "Yüz Bin Müslüman Sultan Ahmet Meydanında Muazzam Bir Miting Akd Eyledi", ikdam, 24 Mayıs 1919, s.1. 
İlk olarak Şair Mehmet Emin Bey oldukça uzun bir konuşma yapmış ardından basın adına Fahrettin Hayri Bey kürsüye çıkmış ve Tevfik Fikret'ten bir şiir okuyarak duygulara tercüman olmuştur. Mitingin tek kadın hatibi olan Halide Edip Hanım işgalci güçlerin yaptığı zulüm ve haksızlıkları kınayan konuşmasında şunları söylemiştir:

“Bugün karşınızda yükselen ses Müslüman kardeşlerin sesidir. Esaret boyunduruğu can damarlarına geçmiş milletler bizim felaketimiz karşısında gür sesleriyle bağırıyorlar. Ben kardeş, Müslüman dünyalarına sizim namınıza hitap ediyorum; davamız şudur: zaten elinden tutanları kalmayan, ellerini bacaklarını kaybeden gazilerimiz, şehitlerimiz namına davamızı ilan ediyorum. Bu davam da Türkiye'nin hak ve istiklalidir. Türkler Türkiye'nin ebedi haklarına asla dokundurmayacaklar, yarın hakkın mahkeme-i kübrası önünde zalimlerin hepsi mahkemeye çekilecek, onlara bizim kanlarımızı döktürdünüz diyecekler..." 45

Halide Edip Hanım hem Türk milletine hem de İslam dünyasına seslenerek işgalcilere karşı mücadeleye çağırmıştır. Konuşmasının sonunda miting meydanını dolduran kalabalığa bayrak, hak ve istiklal için can vermekten çekinmeyeceği, hiçbir kuvvete boyun eğmeyeceği konusunda defalarca yemin ettirmiştir. Konuşmasının sonunda halk galeyana gelmiş meydanı inleten "vallahi sesleriyle" Halide Edip Hanım'ın çağrısına karşılık vermiştir. Halide Edip Hanım, büyük ölçüde milli ve dini motiflere yer verdiği bu konuşması ile açıkça halkı fiili mücadeleye davet etmiştir. Bu nedenle Halide Edip Hanım'ın konuşması yer yer sansüre uğramıştır. Ancak mütareke dönemi mitinglerinin en akılda kalan, en etkili ve en unutulmaz konuşması olmuştur. İtilaf Devletlerinin baskısı üzerine Halide Edip Hanım hakkında bu konuşma nedeniyle tutuklama kararı çıkmıştır. ${ }^{46}$

Miting sonunda alınan kararlarda; işgal edilen noktaların boşaltılıncaya kadar makam-ı saltanat etrafından Türk halkının demir bir çember olacağı, memlekette siyasi ihtirasların sona ermesi gerektiği belirtilmiştir. Ayrıca heyecanlarını kasten sakinleştirmek isteyenleri lanetlediklerini ve saltanat şurasının olağanüstü toplanmasının gerektiği belirtilmiştir. ${ }^{47}$

Sultan Ahmet mitingini işgalci güçler endişe ile takip etmişler hatta miting alanını tayyare ile havadan izlemişlerdir. İtilaf Devletleri ve hükümet çevreleri arka arkaya yapılan İstanbul mitinglerinden özellikle de 23 Mayıs'ta yapılan Sultan Ahmet Mitinginden rahatsız olmuşlardır. Bu nedenle 25 Mayıs'ta Beyazıt Meydanı'nda ve Taşlık'ta (Beşiktaş) yapılacak mitingler Polis Müdürlüğünce engellenmiştir. ${ }^{48}$ Damat Ferit Hükümeti İngilizlerin de baskıları sonucu mitingleri yasaklamıştır. ${ }^{49}$

Yasaklara rağmen çeşitli okulların ve esnaf cemiyetlerinin de katımıyla Sultan Ahmet'te 30 Mayıs 1919 günü Cuma namazı münasebetiyle "dua günü" adı altında bir miting daha düzenlenmiştir. Polis Müdürlüğü toplantıya sadece dini mahiyet taşıması ve Sultanahmet Cami'i içinde kalması şartıyla özel izin vermiştir. ${ }^{50}$ Toplantı için basın yoluyla da çağrıda bulunulmuştur. Örneğin İkdam Gazetesi sür manşetten "Bugün Sultan Ahmet'teki Muazzam Mitinge Gidiniz" başlığıyla çağrıda bulunarak mitingi düzenleyen

45 Arıburnu, a.g.e., s.46.

46 “İstanbul'un Bütün Müslüman Halkı, Hakkını İstemek, Adaletsizliğe Bağırmak İçin Dün Sultan Ahmet'te Toplandı", Hadisat, 24 Mayıs 1919, s.1; "Yüz Bin Müslüman Sultan Ahmet Meydanında Muazzam Bir Miting Akd Eyledi", İkdam, 24 Nisan 1919, s.1.

47 Arıburnu, a.g.e., s.50-51; Fahri Yetim, "Millî Mücadele Döneminde Kamuoyunun Oluşmasında Mitinglerin İşlevi", Eskişehir Osmangazi Üniversitesi Sosyal Bilimler Dergisi, 8 (1), 2007, s.7.

48 “Mitinglerin Men'i”, İkdam, 26 Mayıs 919, s.2; Kaplan, a.g.e., s.77; İnan, a.g.e., s.106.

49 Saruhan, a.g.e., s.100.

50 Ferhat Uyanıker, Millî Mücadelede Türk Kadını, Genelkurmay ATASE Yayınları, Ankara 2009, s.28. 
heyetin yayınladığı beyannameye yer vermiştir. Ancak bu beyanname bir cuma duasına davet şeklindedir. Cuma günü resmi dua günü olarak kabul edildiğinden o yüzden Fatih, Sultanahmet, Beyazıt camilerinde cuma namazından sonra kurtuluş için dua edileceği, vatanını seven herkesin bu toplantılara katılmasının bir dini vecibe olduğu belirtilmiştir. ${ }^{51}$

Cuma duası için çağrı yapılarak yasağa rağmen İtilaf devletlerinin gözünün önünde Sultanahmet Meydanı'nda ikinci kez büyük bir miting daha yapılmıştır. Cuma namazını müteakip bir hoca kürsüye çıkmış ve halka tekbir almalarını söylemiştir. Bundan sonra İsmail Hakkı Bey kürsüye çıkmış ve bir konuşma yapmıştır. Vatanın kurtuluşu ve İzmir şehitleri için dualar edilen daha çok dini nitelikli mitingin tek kadın konuşmacısı Asri Kadınlar Cemiyeti üyesi ve Darülfünun öğrencilerinden Şukufe Nihal Hanım olmuştur. Vatan sevgisini dile getiren bir konuşma yapmıştır. ${ }^{52}$ "Mezarımın önüne gelen yabancılar, senin kabrinden cebren ayırmak istedikleri vefakâr çocuklarından birinin sana ebediyen ağlayan mezarı karşısında her zaman bu memleketin garibi olduklarını anlayarak titremeyeceklerdir." sözleri ile halkı galeyana getirmiştir. Ardından Milaslı İsmail Hakkı Bey, Hamdullah Suphi Bey birer konuşma yapmışlardır. ${ }^{53}$ Sultanahmet Mitingi ile ilgili haberler dönemin basınında büyük ölçüde sansüre uğramış örneğin Hadisat Gazetesi'nde haberin başlığı ve bir bölümü boş çıkmıştır. ${ }^{54}$

İtilaf Devletleri'nin denetimi altında olan İstanbul'da yasaklara rağmen 13 Ocak 1920 tarihinde son kez büyük bir miting daha düzenlenmiş ve ülkede yaşanan işgaller kınanmıştır. Mitingin yapıldığı Sultanahmet Meydanı'na yaklaşık 150 bin kişi toplanmıştır. Hatiplerin konuşacağı kürsü bayraklarla donatılmış İstanbul halkı "kürsünün etrafından itibaren Sultan Ahmet Parkının karşısındaki sıra kahvelere kadar" uzanmıştır. Mitinge medrese, sultani gibi bütün okullardan öğrenci ve öğretmenler katılmıştır. Ayrıca İstanbul Muhafızı Said Paşa, polis şube müdürleri de gelmişlerdir. ${ }^{55}$

Rıza Nur ve Hamdullah Suphi Beylerin kürsüye çıktı̆̆ı mitingde tek kadın konuşmacı Muallimler Cemiyeti Başkanı sıfatıyla Nakiye Hanım olmuştur. Nakiye Hanım konuşmasında kadınlara ve erkeklere mücadele için çağrıda bulunmuştur. ${ }^{56}$ Nakiye Hanım'ın Türk kadınının vatanını kurtarmak için mücadeleye hazır olduğunu vurgulayan konuşması Türk ve dünya kamuoyunda büyük yankı uyandırmıştır. Ünlü Fransız dergisi L'Illustration, 7 Şubat 1920 tarihli sayısında yer alan “istanbul'da Bir Gösteri” başlıklı yazısında "yumuşak, etkileyici ve kendinden emin bir sesle haykırarak duygusal ve ateşli sözleri ile dinleyiciler üzerinde büyük bir izlenim bırakan gözlüklü, orta yaşlı ve ciddi görünümlü bir kadın" olarak tasvir ettiği Nakiye Hanım'ın kürsüde alınmış fotoğrafı ile işgal devletlerini kınayan konuşmasına tam sayfa yer vermiştir. ${ }^{57}$

Sultanahmet Mitingini haber yapan İstanbul gazetelerinde de Nakiye Hanım'ın sözleri öne çıkartılmıştır. Tasvir-i Efkâr Gazetesi 15 Ocak 1920 tarihli sayısında Sultanahmet Mitingine dair izlenimlere yer verirken Nakiye Hanım'ın konuşmasından "Fatihlerin Yavuzların Türbelerini Bırakıp Gidecek misiniz? sözlerini başlığına taşımıştır. İlk sayfada

51 “Bugün Sultan Ahmet'teki Muazzam Mitinge Gidiniz", ikdam, 30 Mayıs 1919, s.1.

52 Kaplan, a.g.e., s.77. Hülya Argunşah, Bir Cumhuriyet Kadını Şükufe Nihal, Timaş Yayınları, İstanbul 2011, s.73

53 İnan, a.g.e., s.106; Kaplan, a.g.e., s.77; Arıburnu, a.g.e., s.52-60.

54 Hadisat, 30 Mayıs 1919, s.1.

55 "Hak ve Hakikat Huzurunda Bir Davayı Mukaddes: İstanbul Türkün, Türk İstanbul'undur", Vakit, 14 Ocak 1920, s.1.

56 Arıburnu, a.g.e., s.65-67; “Nakiye Hanım Hemşiremizin Millete Hitabı: Fatihlerin Yavuzların Türbelerini Bırakıp Gidecek misiniz?", Tasvir-i Efkâr, 15 Ocak 1920, s.1; Kaplan, a.g.e., s.77.

57 Nuray Özdemir, Osmanlıdan Cumhuriyete Bir Cemiyet Kadını: Nakiye Elgün, Phoenix Yayınları, Ankara 2014, s.78-79. 
Nakiye Hanım'ın konuşmasına ve fotoğrafına geniş yer vermiştir. Yapılan konuşmalar arasında en güzelinin Nakiye Hanım'ın konuşması olduğuna vurgu yapılarak onun sözlerinden alıntılar yapılmıştır. Özellikle başlıkta da kullanılan "Size memleketimin bir kadını sıfatıyla hitap ediyorum. Fatih'in, Selim'in, Süleyman'ın mezarını, ecdadımızın ebedi abideleri olan camileri, türbeleri bırakıp çıkacak içinizde bir erkek var mıdır? Ben tasavvur etmiyorum. Çıkmayacaksınız, bırakmayacaksınız. Biz de daima sizinle beraber olacağız." sözlerinin kamuoyu oluşturmada ne kadar etkili olduğuna dikkat çekilmiştir. Nakiye Hanım'ın bu düşüncelerinin bütün Türk ve Müslümanların duygularına tercüman olduğu yazılmıştır. ${ }^{58}$

Nakiye Hanım'ın Sultanahmet Mitingindeki konuşması Anadolu kadını üzerinde de derin etkiler bırakmıştır. Anadolu Kadınları Müdafaa-ı Vatan Cemiyeti'nin 6 Şubat 1920 tarihinde toplanan genel kurulunda yönetim kurulu üyelerinden Darüleytam Müdiresi Makbule Rıza Hanım yaptığı konuşmada Nakiye Hanım'a atıfta bulunarak şunları söylemiştir: “... Muallimler Cemiyeti Reisesi Muhterem Nakiye Hanım'ın İstanbul mitinginde dediği gibi Türkler için iki yol vardır, Biri tarihimize şanımızla devam etmek, diğeri gözlerimizle beraber tarihimizi kapayıp ebediyete götürmektir. Evet Hanımefendiler, Türk milleti için üçüncü bir yol yoktur..." ${ }^{59}$ Nakiye Hanım mitinglerde yaptığı konuşmalarla işgalci güçlerin dikkatini çekmiş ve takibata uğramıştır. ${ }^{60}$

Adalet, medeniyet, barış, hürriyet, insaniyet, istiklal, milliyetçilik fikirlerinin işlendiği İstanbul mitinglerinin bıraktığı etki kendilerini kolay bir zafere hazırlamış olan İtilaf Devletlerini tedirgin etmiştir. Bu yüzden mitinglerin yapılmasını engelleyerek çeşitli zorluklar çıkararak halkın katıımını önlemeye çalışmışlardır. Fakat bunun önüne geçememişler ve mitingleri yasaklama yoluna gitmişlerdir. Ancak yasaklara rağmen, Anadolu'nun işgal altında olmayan yerlerinde protesto mitingleri bütün hızıyla devam etmiştir. ${ }^{61}$

\section{G-Yurt Genelinde Yapılan Mitinglerde Kadınlar}

İzmir'in işgali sonrasında ülkenin hemen her şehrinde protesto gösterileri yapılmıştır. Mitinglerde milletçe ülkenin kurtuluşu için çeşitli kararlar alınarak ilgili makamlara telgraflar gönderilerek durum bildirilmiştir. ${ }^{62}$ Anadolu'da yapılan mitinglere kadınların da katılımı yoğun olmuştur. Ancak İstanbul mitinglerinde olduğu gibi kürsüde konuşmacı olarak kadınlar yer almasalar da ilk defa erkeklerle birlikte meydanları doldurmuşlardır. Ya da kadınlardan oluşan miting heyetlerinin girişimiyle sadece kadınların katılımı ile mitingler düzenlenmiş ve İtilaf Devletleri temsilcilerine işgalleri protesto eden telgraflar çekilmiştir. Gerek mitinglerde yapılan konuşmalarda gerekse miting kararlarında İstanbul mitinglerinde işlenen temalara aynen yer verilmiştir.

İzmir'in işgali karşısında Anadolu'da kadınların imzasıyla yayınlanan en erken protestolardan biri Silvan ve çevresindeki kadınlar tarafından İstanbul'daki İtilaf Devletleri temsilciliklerine ve ABD Başkanı Wilson'un eşine hitaben 22 Mayıs 1919'da çekilen telgraf olmuştur. Telgraf Fransızca kaleme alınmış ve "Silvan ve Kulp kazalarında otuz bin kadın

58 "Nakiye Hanım Hemşiremizin Millete Hitabı: Fatihlerin Yavuzların Türbelerini Bırakıp Gidecek misiniz?”, Tasvir-i Efkâr,15 Ocak 1920, s.1.

59 Bekir Sıtkı Baykal, Millî Mücadele'de Anadolu Kadınları Müdafaa-ı Vatan Cemiyeti, ATAM Yayınları, Ankara 1996, s.57.

60 Özdemir, a.g.e., s.82-83.

61 Gülay Sarıçoban, “Milli Mücadelede Anadolu Kadını”, Atatürk Üniversitesi Sosyal Bilimler Enstitüsü Dergisi, Aralık 2017, 21(4), s.1333.

62 Şahingöz, a.g.m., s.729. 
adına" Fatma, Sıdıka, Şerife, Şahende, Adalet, Lutfia, Bedia, Münire, Gülistan, Lamia, Ayşe Hatice hanımları imzasıyla gönderilmiştir. Telgrafta İzmir'in işgalinin insanlık ve adalete tamamen aykırı bir hareket olduğu vurgusu yapılmıştır. ${ }^{63}$

İzmir'in işgalini protesto amaçlı Anadolu'da kadınların düzenlediği ilk mitinglerden biri ise Muğla kadınları tarafından 25 Mayıs 1919 tarihinde yapılmıştır. İzmir'in işgalinden duyulan üzüntüyle Muğlalı kadınlar İnas Sultani Mektebi civarında toplanarak bir miting düzenlemişlerdir. Miting sonrasında Muğlalı 26 kadından oluşan miting heyetince İtilaf Devletleri temsilcilerine ayrı ayrı İzmir'in işgalini protesto ettiklerini beyan eden protesto telgrafı çekilmiştir. "Güzel İzmir'in" işgalinin bütün Türk kadınlarınca asla kabul edilemeyeceği belirtilerek Yunan askerlerinin süratle geri çekilmesini talep etmişlerdir. Protesto telgrafının altında Remziye Kâmil, Rabia Murat, Hayriye Kâmil, Münire Hidayet, Vasfiye Kamil, Melek Faik, Enveriye Hilmi, Kamile Murat, Fitnat Hüseyin, Fitriye Alefullah, Adile Nuri, Kadire Derviş, Mürvet Hasan, Fatma Rıfat, Cevriye Yahya, Lütfiye Fazıl, Mükerrem Şaban, Fahriye Şakir, Şaziye Yusuf, Refika Mehmed, Zehra Osman, Fahriye Hamza, Hıra Ali (?), Gülsüm Abdullah, Hatice Ömer (?), Güzide Sıdkı hanımların imzalarına yer verilmiştir. ${ }^{64}$

Ankaralı kadınlar ise 28 Mayıs 1919 günü İzmir'in işgali üzerine İnas Mektebi'nde bir toplantı yapmışlardır. On üç bin Türk ve İslam hanımı adına Ankara valisi Muhiddin Bey tarafından Hükümetten İstanbul'da bulunan İtilaf Devletleri temsilcilerine ve Amerikan devlet başkanına “Güzel İzmir'in işgalinden büyük üzüntü duyduklarını ve İtilaf devletlerinin adil ve haktan yana olacaklarına dair ümit var olduklarını bildiren protesto namelerinin gönderilmesini talep etmiştir. ${ }^{65}$

Bodrumlu kadınlar da 30 Mayıs 1919'da düzenledikleri bir miting ile İzmir ve çevresinin işgalini protesto etmişlerdir. Toplantı sonunda işgalden duyulan üzüntüyü dile getiren bir mektup hazırlanarak İtalya, İngiltere, Fransa ve Amerika Yüksek Komiserliklerine iletilmek üzere oradaki İtalyan Birliği'nin komutanına göndermişlerdir. Mektupta Bodrum Kadınları Miting Heyeti Başkanı Emine Ferid ve Kadınlar Yüksek Heyeti Başkanı Netice ile 100 üyenin imzalarını yer almıştır. Bodrum kazasının bütün kadınlarının büyük bir acı içerisinde bir araya gelip bir miting düzenlediği ve vatının ayrılmaz bir parçası olan güzel İzmir'in Yunanlılar tarafından haksız yere işgal edildiği ve bunun milli haklara yönelik büyük bir darbe olduğu bildirilmiştir. İşgali şiddetle protesto ettiklerini bildirmişlerdir. İtilaf Devletleri hükümetlerinden de haklarının garanti altına alınmasını ısrarla talep ettiklerini ve buna sessiz kalınmayacağı ve Yunan birliklerinin en kısa zamanda İzmir'den geriye çekileceğine inandıklarını bildirmişlerdir. Aynı gün Bodrumlu kadınlar İngiltere, Fransa Amerika ve İtalya Başbakanlarına ve eşlerine de birer protesto telgrafı göndermişlerdir. Bodrum kadınları miting heyeti başkanı Emine Ferid ve Kadınlar Yüksek Heyeti Başkanı Netice, üyeler; Emine Ali, Hüseyin Netice, Yusuf Zühra ve Musevi kadınlarını temsilen Perla Galanti imzasıyla gönderilen telgrafta Bodrumlu kadınlar "gözbebeğimiz İzmir'imizin bir an önce bize geri verilmesini" talep ediyoruz şeklinde isteklerini bildirmişlerdir. ${ }^{66}$

Alaşehir'de faaliyet gösteren Alaşehir İslam Kadınları Cemiyeti ise önce İtilaf Devletlerinin İstanbul'daki temsilcilerine 18 Mayıs 1919 tarihli “Alaşehir ve havalisi İslam Kadınları namına Makbule ve Nebile "imzasıyla İzmir'in işgalini protesto eden bir telgraf

63 BOA, HR:SYS, 3552-5.

64 BOA; HR.SYS, 2552-5.

65 BOA, HR:SYS, 2552-6.

66 Mevlüt Çelebi, "Menteşe Sancağı'nda İtalyan ve Yunan İşgallerine Tepkiler", Muğla Üniversitesi Sosyal Bilimler Enstitüsü Dergisi (iLKE), Güz 2008, Sayı:21, s.91-92. 
göndermişlerdir. İzmir'in işgaline olan tepkilerini duyurmak için 2 Haziran 1919 tarihinde çarşı kenarında Yağhane Camii'nde toplanarak küçük bir miting düzenlemişlerdir. Ülkenin işgalden kurtarılması için yapılması gerekenlerden bahsedilmiş ve ülke için müdafaaya Alaşehirli kadınların hazır olduğu ilan edilmiştir. ${ }^{67}$

Yunan işgalinin 1919 yılı sonlarında genişlemesi ve İzmir'de yaşanan mezalimden dolayı kasım ayından itibaren protesto nitelikli toplantılar yeniden düzenlenmeye başlanmıştır. Sivas'ta Melek Reşit Hanım'ın öncülüğünde 5 Kasım 1919 tarihinde kurulan Anadolu Kadınları Müdafaa-ı Vatan Cemiyeti'nin girişimi 28 Kasım 1919 Cuma günü bir toplantı düzenlenmiştir. Toplantıda söz alan Cemiyet Başkanı Melek Hanım "Bugün buraya toplanmaktaki maksadımız, memleketimiz hakkında biraz görüşmek, dertleşmek, ağlaşmak, Cenab-ı hakka yalvarmak, lazım gelirse vatanın müdafaası için hatta ölüme bile katlanmaktır" sözleri ile başladığı konuşmasında önce ülkenin işgal altındaki durumunu açıklamıştır. Ülkenin muhafazası için, hukuk için bu cemiyetin kurulduğunu ve bunlar için çalışacaklarını ifade etmiştir. Aynı toplantıda Darüleytam Müdiresi Makbule Hanım da uzun bir konuşma yapmıştır. "Yemin ediyoruz, ahdediyoruz; Memleketimizi düşmana vermemek için erkeklerimizle beraber çalışacağız. Bu kararımızı bütün Anadolu'daki Türk ve Müslüman hemşehrilerimize bildireceğiz. Hiç şüphe etmem ki onları da kendimizle beraber müdafaa yolunda göreceğiz. Bütün Anadolu kadınlarının memleketlerini erkekleriyle, çocukları ve ihtiyarları ile müdafaa edeceklerini Amerika, İngiltere Fransa ve İtalya mümessillerine de söyleyeceğiz Hakka riayet etmelerini rica edeceğiz. Hakkımızı ölünceye kadar talep edeceğiz." sözleri ile Sivaslı kadınların vatanı için ölmeye hazır olduğunu dile getirmiştir. Ayrıca bu kararı önce Padişaha ve Dâhiliye Nazırına bildireceklerini de ifade etmiştir. ${ }^{68}$ Sivas merkez vilayetteki İslam kadınlarının bu toplantısı Sivas Valisi Reşit Paşa tarafından Sadarete bildirilerek 28 Kasım 1919 tarihinde kadınlar tarafından kaleme alınan protesto telgrafı itilaf devletleri temsilcilerine gönderilmiştir. ${ }^{69}$

Anadolu Kadınları Müdafaa-ı Vatan Cemiyeti Millî Mücadele döneminin en etkin kadın örgütü olup Amasya, Erzincan, Konya, Burdur, Bolu gibi şehirlerde de şubeler açmıştır. Heyet-i Temsiliye Başkanı Mustafa Kemal Paşa ile de sürekli iletişimde olan cemiyet yurt genelinde vatanseverlik duygularını canlı tutarak kadınları işgaller karşısında tepki gösterme konusunda örgütlemiştir. Gerekirse kadınların da cepheye gideceği tekrarlanarak erkekleri savaşmaya özendirip cesaretlendirmeye yönelik propaganda hedefli faaliyetlerde de bulunmuştur. Küçük Anadolu kentlerinde yapılan toplantılarda söz alan kadınlar milliyetçi bir söylemle işgallere karşı tepkilerini sert bir şekilde göstermişlerdir.

Erzurumlu kadınlar ise Erzurum İslam Kadınları adıyla bir komite oluşturmuşlar ve 29 Kasım 1919'da Muradiye Camii'nde bir araya gelerek mevlit okuyup işgaller karşısında ülkenin kurtuluşu için dualar etmişlerdir. Toplantıda İnas Mektebi Müdiresi Faika Hakkı Hanım tarafından bir konuşma yapılmış Sadarete, Dahiliye Nezaretine ve İstanbul'daki İtilaf Devletleri temsilcilerine, ABD Senatosuna Vali Reşit Bey'in imzasıyla bir protesto mektubu göndermişlerdir. İtilaf Devletlerinin yaşanan işgallere artık müsamaha göstermemesi ve Anadolu halkının haykırışlarına kulak verilmesi için şu çağrıda bulunulmuştur:

“...hala sulh akdolunmadığı gibi İzmir'den başlayarak Antalya, Urfa, Maraş’ta biz Osmanlılar haklarına zalimane ve gaddarane muamelatı enva tatbik ediliyor. Kollarımızı bağlayarak gözlerimizin önünde baltalarla evlatlarımızın kanlarını akıtanları, erkeklerimizi

bir araya toplayarak ateşle yakanları, kadın ve çocuklarımızdan pek çoklarının azayı

67 Kaplan, a.g.e., s.80.

68 Baykal, a.g.e., s.2-3.

69 BOA, DH.ŞFR, 652-88. 
mühimmesini kat ederek mürde bir halde bırakanları, memleketimizi viraneliğe çevirdikleri, sizlerin tahkikatınızla biletraf anlaşılmış iken biz Osmanlılara insafınızı çevirmeyerek elan o gibi canileri himaye ve vikaye etmek teşebbüsünü anlayamıyoruz... Wilson Cenapları ekseriyetin hukuku ekalliyetin efradı ahaliyesine feda edilemez diyorlar. Ingilizlerle Fransızlar ve İtalyanlar da ilhaksız, tazminatsız sulh akdedeceklerini kâinata ilan ediyorlardı. Söz, insaniyetlerin hakkı tabiisi izzetinefsidir. Daha doğrusu namustur... Biz Erzurum muhiti düveli müttefikenin namuslarına müdahalesini menedeceklerine kaniyiz. Bu ciheti medeni ve adaletin şefkat ve insaniyetin timsali olan itilaf devletlerinin nazarı dikkatlerine arz ile mevcudiyet ve istiklalimizi muhafazaya kâfi, insanlığa layık devamlı bir sulhun temini esbabını izhar buyurmalarını insaniyet namına rica ederim." 70

Erzurumlu kadınlar barış antlaşmasının hala yapılmamış olmasına dikkat çekmiş ve Anadolu'nun işgalini ve halkın kıyılmasını, bu arada Amerika gibi Türklerin dostu olduklarını söyledikleri halde, onlardan yana herhangi bir müdahalede bulunmaktan çekinden güçlerin bu davranışları lanetlenmiştir. ${ }^{71}$

Kastamonulu hanımlar da işgallere karşı çıkmışlar ve tarihi bir miting düzenlemişlerdir. Kastamonu Müslüman Kadınları adına Zekiye Hanım'ın başkanlık yaptığı miting düzenleme heyeti oluşturulmuştur. Kamuran, Saime, Bedriye, Münire, Refika ve Neyyire Hanımlar da görev almışlardır. 10 Aralık 1919 Çarşamba günü Darülmuallimat bahçesinde yapılan mitinge üç binden fazla kadın katılmıştır. Polis Müdürü Halil Bey'in eşi Zekiye Hanım, Darülmuallimat müdiresi Hikmet Hanım, yardımcısı İclal Hanım ve Refika Hanımlar birer konuşma yapmıştır. Zekiye Hanım heyecanlı konuşmasında işgalleri, vahşetleri ve haksılıkları şiddetle protesto etmiştir. Gerekirse kadınların da cepheye gideceğini ifade etmiştir. ${ }^{72}$ Avrupa devletlerine duydukları güvenin sarsıldığını, işgal altında bulunan yerlerin korkunç bir baskı altında kaldığını anlatarak işgallere boyun eğmeyeceklerini söylemiştir. ${ }^{73}$ Mitingde benimsenen ilkeler doğrultusunda Padişaha, Sadrazama, ABD ve Fransa Cumhurbaşkanlarının eşlerine, İngiltere ve İtalya kraliçelerine ve Hindistan İmparatoriçesine telgraf çekilmesi kararı alınmıştır. Kastamonu Müslüman kadınları namına miting heyeti imzasıyla çekilen bu telgraflarda Urfa, Maraş ve Antep'in işgali de protesto edilmiş ve ülkenin parçalanmasına izin verilmeyeceği büyük bir kararlılıkla ifade edilmiştir. ${ }^{74}$

Edirne'de de 18 Aralık 1919 tarihinde on binden fazla kadının katılımıyla Selimiye Cami'nde mevlid-i şerifin okunduğu bir toplantı yapılmıştır. İzmir'in Yunanlılar tarafından halen işgal altında olmasından Edirne kadınlarının duyduğu üzüntü ile reji nazır-ı sabıkı Rıza Bey ailesi Sabriye, Eşraftan Paşazade İbrahim Bey haremi Dilara, Eşraftan Mehmet zade zevcesi İsmet, Eşraftan Doktor Hasan Bey refikası Hayriye, Yakup Efendi zade Derviş Bey ailesi Nadire Doktor Hasan Bey refikası Hayriye, Edirne Eşrafından Hüsameddin Bey ailesi Pakize, Eşraftan merhum İbrahim Bey ailesi Hürmüz imzası ile İtilaf devletlerinin İstanbul'daki temsilcilerine birer protesto telgrafı çekilmiştir. ${ }^{75}$

Konya'da ise Yunanlıların İzmir ve çevresinde yaptıkları mezalim ile Fransızların Ermenilerle iş birliği yaparak Adana'da yaptıkları işgal ve haksızlıkları protesto etmek amacıyla 70 Cahit Çaka, Tarih Boyunca Harp ve Kadın, As. Fb. Basımevi, Ankara 1948, s.41-42.

71 Sarıçoban, a.g.e., s.1335; Bernard Caporal, Kemalizmde ve Kemalizm Sonrasında Türk Kadını, Türkiye İ̧̧ Bankası Yayınları, Ankara 1982, s.171.

72 "Hanımlarımızın Mitingi”, Açık Söz, 14 Aralık 1919, s.1-2; Mustafa Eski, “ilk Kadın Mitingi”, Kastamonu’da Illk Kadın Mitingi'nin 75. Yıldönümü Uluslararası Sempozyumu, 10-11 Aralık 1994, Kastamonu, ATAM Yayınları, Ankara 1996, s.40.

73 Kaplan, a.g.e., s.114.

74 BOA, I..DUiT, 118-162; Eski, a.g.m., s.40.

75 BOA, HR.SYS, 2552-7. 
kadınlar tarafından 8 Ocak 1920'de bir toplantı yapılmıştır. Yaklaşık beş bin Türk kadınının katılımıyla Şerafettin Cami'nde şehitlerin ruhuna okunmak üzere bir mevlit düzenlenmiştir. Bir mitinge dönüşen bu toplantı Anadolu Kadınları Müdafaa-ı Vatan Cemiyeti'nin Konya şubesi tarafından organize edilmiştir. Kadınlar Paris Barış Konferansı'nda alınan kararlara karşı çıkarak milli haysiyeti ihlal edecek hükümlerin asla tanınmayacağını ilan etmişlerdir. Türk Müslümanlarla meskûn savaştan önceki sınırlar dâhilinde İstanbul'un saltanat ve hilafet merkezi olmak üzere "Müstakil bir Türkiye'nin bekasını ve Wilson Prensiplerinin harfiyen tatbikini temin etmeyen bir sulhun asırların mağlup edemediği Türk milletine kabul ettirilmesinin imkansız" olduğuna dair bir beyanname yayınlamışlardır. ${ }^{76}$ Konyalı kadınlar kendi aralarından seçtikleri ve başkanlığını aynı zamanda Anadolu Kadınları Müdafaa-ı Vatan Cemiyeti Konya Heyet-i Merkeziyesi başkanı da olan Kevser Hanım'ın yaptığı heyet ile bu beyannamenin birer suretini şehirdeki İngiliz, İtalyan ve Fransız temsilcileri ile valiliğe vermişlerdir. Ayrıca 2.Ordu Komutanı Fahrettin Bey'i de makamında ziyaret ederek yayınladıkları beyannamenin bir suretini taktim etmişlerdir. Bu protesto metninin altında heyet üyesi olan şu kadınların imzası vardır: Heyet başkanı Çelebi Efendi Haremi Kevser, heyet başkan yardımcısı Tahir Paşa kerimesi Şerife ile üyeler Divan-ı Harp Reisi Binbaşı Rüştü Bey'in haremi Zühre, Tahir Paşa kerimesi Havva, Tahir Paşa Kerimesi Naciye, Bahaaddin Çelebi haremi Suzide, Karahafız Zade Mustafa Efendi haremi Aliye, Kazım Bey haremi Nazmiye, Sabık Mebus Mehmet Emin Bey Haremi Lütfiye, Eczacı Hüsamettin Bey Haremi Şeibe, Tüccardan Yusuf Efendi Haremi Emine, Tüccardan Mehmet Ali haremi Hatice, Faik Bey haremi Vicdan, Erkan-ı Harpten Mütekaid Şevki Bey haremi Firdevs, Tüccardan Ali Bey haremi Feime, Dar-ül Muallimat Heyet-i Temsiliye namına Fransızca ve Piyano muallimesi Emine Ferhunda, Çelebi Haremi Sıdıka. ${ }^{77}$

Anadolu'daki protestolar 16 Mart 1920 tarihinde İstanbul'un İngilizler tarafından işgali üzerine daha da artmıştır. Yaşanan işgal ülke genelinde derin bir üzüntüye yol açmış ve halk tepkisini meydanlarda toplanarak göstermiştir. 17 Mart 1920'de Erzurum, Çorum, Kastamonu, 19 Mart 1920'de Yozgat, 20 Mart 1920'de Sinop, Tokat, Bitlis, Trabzon, Çine, Gümüşhane, Kayseri, Malatya, Diyarbakır, 22 Mart 1920'de Konya, 15 Mayıs 1920'de Ankara'da yapılan mitinglere katılanların çoğunluğunu kadınlar oluşturmuştur. ${ }^{78}$

\section{SONUÇ}

İzmir'in Yunanlılar tarafından işgali üzerine başta İstanbul'da ve Anadolu'nun hemen her şehrinde mitingler düzenlenmiş protesto gösterileri yapılmıştır. Bu haksızlığa dünya kamuoyunun dikkatini çekmek üzere mitinglerde alınan kararlar çerçevesinde Avrupa ve Amerika'nın İstanbul'daki temsilcilerine, saraya, sadarete protesto telgrafları çekilmiştir. Mitinglerin büyük bir heyecan içerisinde yapılmasında Mustafa Kemal Paşa'nın 28 Mayıs 1919 tarihli Havza Genelgesi'nin etkisi de büyük olmuştur.

Mitinglerde halk haksız işgaller hakkında bilinçlendirilirken, bu durum karşısında sessiz kalınmaması ve ülkenin kurtuluşu için çağrı yapılmıştır. Özellikle İstanbul'da düzenlenen büyük mitinglerde ilk defa kadınlar ve erkekler aynı meydanlarda seslerini duyurmuşlardır. İstanbullu kadınlar gerek dinleyici gerekse konuşmacı olarak mitinglere geniş katılım göstermişlerdir. Halide Edip Adıvar, Nakiye Elgün, Şükufe Nihal Başer gibi dönemin aydın kadınları miting kürsülerinden yaptıkları etkili konuşmalarla tüm milletin sesi olmuşlardır. Ülkenin kurtuluşu için erkeklerle birlikte mücadeleye hazır olduklarını 76 BOA, DH. ŞFR, 643-101, R.25.08.1335, Afet İnan, Tarih Boyunca Türk Kadının Hak ve Görevleri, Milli Eğitim Basımevi, İstanbul 1975, s.108.

77 Ahmet Avanas, Milli Mücadelede Konya, ATAM Yayınları, Ankara 1998, s.39-41.

78 BOA, i.DUiT, 118-156, H-03-03-1338; Kaplan, a.g.e., s.80-81. 
dünyaya duyurmuşlardır. Anadolu'da düzenlenen mitinglerde ise dinleyici olarak kadınların katılımı yoğun olmuşsa da kadın konuşmacılara söz verilmemiştir. Ancak Muğla, Edirne, Kastamonu, Konya gibi şehirlerde sadece kadınların katıldığı mitingler, daha çok dini toplantılar şeklinde yapılmış kadın hatipler etkili konuşmalar yapmışlardır. Miting heyetleri oluşturulmuş ve alınan kararlar İstanbul'daki İtilaf Devletleri; temsilcilerine, parlamentolarına, devlet başkanları ile Padişaha, Sadarete telgraf çekilerek bildirilmiştir. Hatta kamuoyu oluşturulmak isteğiyle miting kararları devlet başkanları eşlerine dahi gönderilmiştir. Özellikle ABD Başkanı Wilson'un eşine ülkenin hemen hemen her yerinden telgraf çekilerek kadın dayanışması için çağrıda bulunulmuştur. Ülkenin çeşitli şehirlerinden çekilen bu protesto beyannamelerinin içeriği hemen hemen aynı formda hazırlanmış olup Türklük, Müslümanlık, hak, adalet, cihat, vatan sevgisi, analık, kadınlık gibi imgelere yer verilmiştir.

Zaman zaman İstanbul Hükümeti, İtilaf Devletleri, ABD Başkanı Wilson ve hatta Padişah işgallere Kadınların protesto amaçlı miting ya da toplantıları genellikle camilerde ve kız okullarında yapılmış daha çok milli ve dini bir nitelik taşımıştır. Türklük, Müslümanlık, analık, şehitlik gibi motiflerin yer aldığı konuşmalar miting kürsülerinden halkı oldukça coşturmuştur. Mitinglerde konuşma yapan kadınların çoğunluğunu cemiyet üyeleri, öğretmenler ve kız öğrenciler oluşturmuştur. Vatanı işgalden kurtarmak için canlarını seve seve vereceklerini vurgulayan kadınların yaptığı konuşmalar kamuoyunda daha çok ilgi görürken etkisi de fazla olmuştur. Dönemin basını da mitinglerle ilgili haber yaparken özellikle kadınların yaptıkları toplantılara ve konuşmalara geniş yer vermiştir. Millî Mücadele taraftarı gazeteler "kadınlar destek veriyorsa erkekler de direnişi tüm gücüyle desteklemeli" mesajını miting haberleri üzerinden geniş kitlelere duyurmuşlardır. Mitingler halk arasında millî birlik ve beraberlik ruhunu güçlendirirken millî mücadele fikrinin geniş kitlelerce benimsenmesinde önemli rol oynamıştır. Yurt genelinde yapılan mitingler ulusal direniş yönünde kamuoyunun oluşmasında, ulusal bağımsızlık doğrultusunda kitlelerin mobilize oluşunda, Kuva-yı Milliye ruhunun kadın-erkek geniş kitlelere yayılmasında etkili olmuştur. Kadınların mitinglerde yaptığı konuşmalar propaganda amaçlı da kullanılmış Anadolu kadının uyanışında ve Milî̀ Mücadeleye gerek cephede gerekse cephe gerisinde yaptığı hizmetlerde bir başlangıç olmuştur. Türk kadını teşkilatlanarak bütün imkanlarını ordu için seferber etmekten geri durmamıştır. Kadınlar Milîi Mücadele'nin her aşamasında yer almışlardır.

\section{KAYNAKÇA}

\section{1-Arşivler}

Türkiye Cumhuriyeti Cumhurbaşkanlığı Devlet Arşivi Başkanlığı Osmanlı Arşivi (BOA)

\section{2-Süreli Yayınlar}

Açık Söz

Genç Kadın

Hadisat

İkdam

Inci

Memleket

Tanin

Tasvir-i Efkâr

Vakit 


\section{3-Kitap ve Makaleler}

Adıvar, Halide Edip (1992), Türkün Ateşle Imtihanı, İstanbul: Atlas Kitabevi.

Argunşah, Hülya (2011), Bir Cumhuriyet Kadını Şükufe Nihal, İstanbul: Timaş Yayınları.

Arıburnu, Kemal (1975), Millî Mücadelede İstanbul Mitingleri, Ankara: Yeni Desen Matbaası.

AVANAS, Ahmet (1998), Millî Mücadelede Konya, Ankara: ATAM Yayınları.

Aydın, M. Korkud (2011), Millî Mücadele Dönemi istanbul Öğrenci Hareketleri (19181922), Elâzığ: Fırat Üniversitesi Sosyal Bilimler Enstitüsü Basılmamış Yüksek Lisans Tezi.

Baykal, Bekir Sıtkı (1996), Millî Mücadele'de Anadolu Kadınları Müdafaa-I Vatan Cemiyeti, Ankara: ATAM Yayınları.

Caporal, Bernard (1982), Kemalizmde ve Kemalizm Sonrasında Türk Kadını, Ankara: Türkiye İş Bankası Yayınları.

Çaka, Cahit (1948), Tarih Boyunca Harp ve Kadın, Ankara: As. Fb. Basımevi.

Çakır, Serpil (2011), Osmanlı Kadın Hareketi, İstanbul: Metis Yayınları.

Çelebi, Mevlüt (2008), “Menteşe Sancağı'nda İtalyan ve Yunan İşgallerine Tepkiler”, Muğla Üniversitesi Sosyal Bilimler Enstitüsü Dergisi (ilke), S.21, s.81-96.

(1912) Darülfünun Konferans Salonunda Kadınlarımızın İçtimaları, İstanbul: Tanin Matbaası.

Engünün, İnci-Cumbur, Müjgan-Özdemir, Cahide (1983), Millî Mücadelede Türk Kadını, Ankara: Türk Ticaret Bankası Yayınları.

Eski, Mustafa (1996), “ilk Kadın Mitingi”, Kastamonu'da IIlk Kadın Mitingi'nin 75. Yıldönümü Uluslararası Sempozyumu, Kastamonu, 10-11 Aralık 1994, Ankara; Atam Yayınları, s.34-46.

Filmer, Sabahat (1983), Atatürk Yolunda Büyük Adımlar, İstanbul: Gül Matbaası.

İnan, Afet (1975), Tarih Boyunca Türk Kadının Hak Ve Görevleri, İstanbul: Milli Eğitim Basımevi.

Kaplan, Leyla (1998), Cemiyetlerde ve Siyasi Teşkilatlarda Türk Kadını (1908-1960), Ankara; Atam Yayınları.

Köroğlu, Erol (2004), Türk Edebiyatı ve Birinci Dünya Savaşı (1914-1918) Propagandandan Milli Kimlik Inşasına, İstanbul: Iletişim Yayınları.

Kurnaz, Şefika (2012), Balkan Savaşında Kadınlarımız, İstanbul: Ötüken Neşriyat.

Kurnaz Şahin, Feyza (2008), "Mağdur ve Sembol: I. Dünya Savaşı Yıllarında Osmanlı Devleti'nde Kadına Yönelik Propaganda", Selçuk Üniversitesi Türkiyat Araştırmaları Dergisi, Güz (44), s.217-243.

Özdemir, Nuray (2014), Osmanlıdan Cumhuriyete Bir Cemiyet Kadını: Nakiye Elgün, Ankara: Phoenix Yayınları.

Sarıçoban, Gülay (2017), "Millî Mücadelede Anadolu Kadını”, Atatürk Üniversitesi Sosyal Bilimler Enstitüsü Dergisi, Aralık, 21(4), s.1331-1346.

Saruhan, Zeki (2006), Kurtuluş Savaşı Kadınları, Ankara: Cem Web Ofset.

Sunata, i. Hakkı (2019), İstanbul'da İşgal Yılları, İstanbul: Türkiye İş Bankası Yayınları.

Şahingöz, Mehmet (2002), "Millî Mücadelede Protesto ve Mitingler", Türkler, C.15, Ankara: Yeni Türkiye Yayınları, s.726-744. 
Şahingöz, Mehmet (2016), "Millî Mücadelede Yapılan Mitinglerde Türk Ocaklarının Rolü ve Hamdullah Suphi", Hamdullah Suphi ve Gagauzlar, Ankara: Türk Yurdu Yayınları, s. 29-48.

Toprak, Zafer (2017), Türkiye'de Yeni Hayat Inkılap ve Travma (1908-1928), İstanbul: Doğan Kitap.

Türkmen, Zekeriya (2016), Millî Mücadele Yıllarında İstanbul Mitingleri, Ankara: Berikan Yayınevi.

Uyanıker, Ferhat (2009), Millî Mücadelede Türk Kadını, Ankara: Genelkurmay ATASE Yayınları.

Yalçın, Hülya (2019), Cumhuriyet Dönemi Kadın Imajı İşsası (1928-1938), Ankara: Hacettepe Üniversitesi Atatürk İlkeleri ve İnkılap Tarihi Enstitü Basılmamış Yüksek Lisans Tezi.

Yetim, Fahri (2017), "Millî Mücadele Döneminde Kamuoyunun Oluşmasında Mitinglerin İşlevi", Eskişehir Osmangazi Üniversitesi Sosyal Bilimler Dergisi, 8 (1).

\section{EKLER}

Ek 1: Fransız Dergisi L'Illustration'ın 7 Şubat 1920 tarihli sayısında yer alan Nakiye Hanım'ın miting kürsüsünde çekilmiş fotoğrafi.

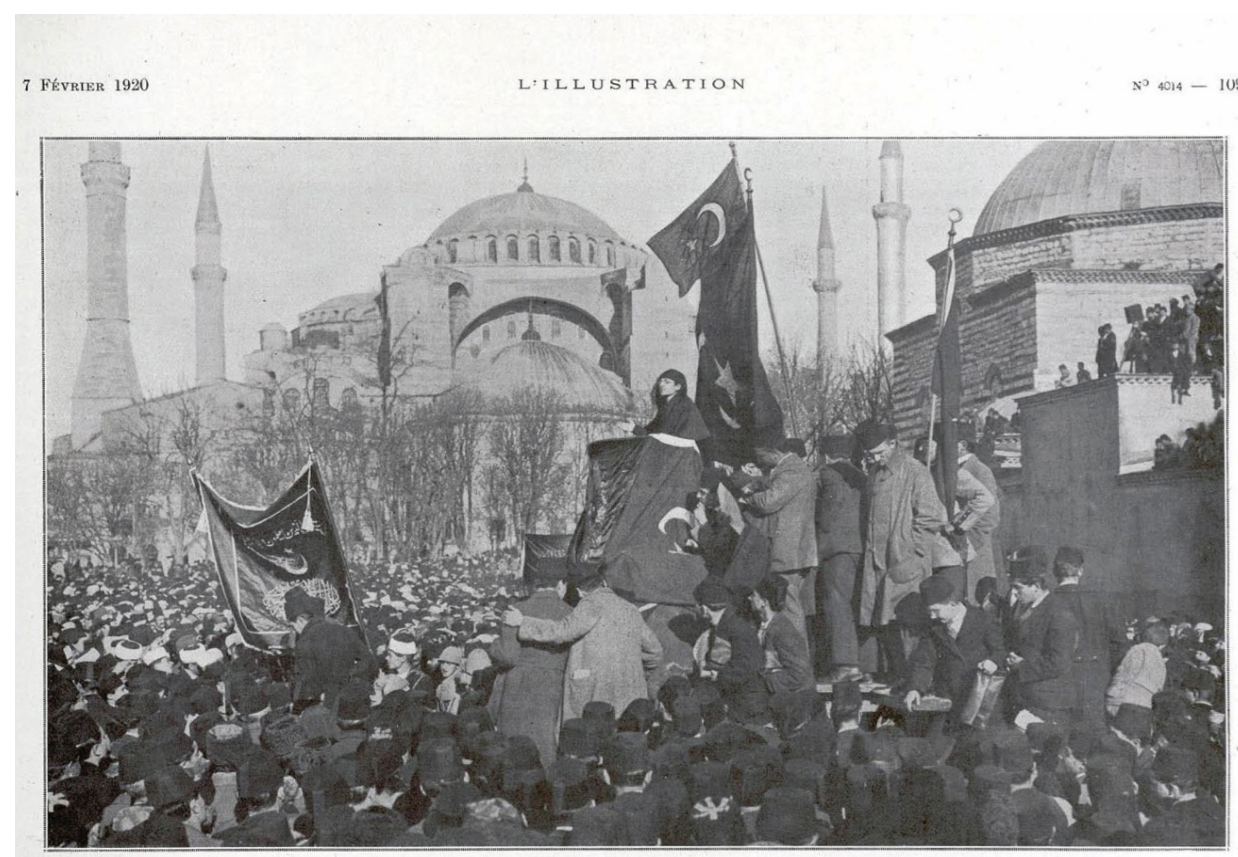

Kaynak: Özdemir, a.g.e., s.79. 
Ek 2: Silvan ve çevresindeki kadınlar tarafindan çekilen 22 Mayıs 1919 tarihli protesto telgrafi

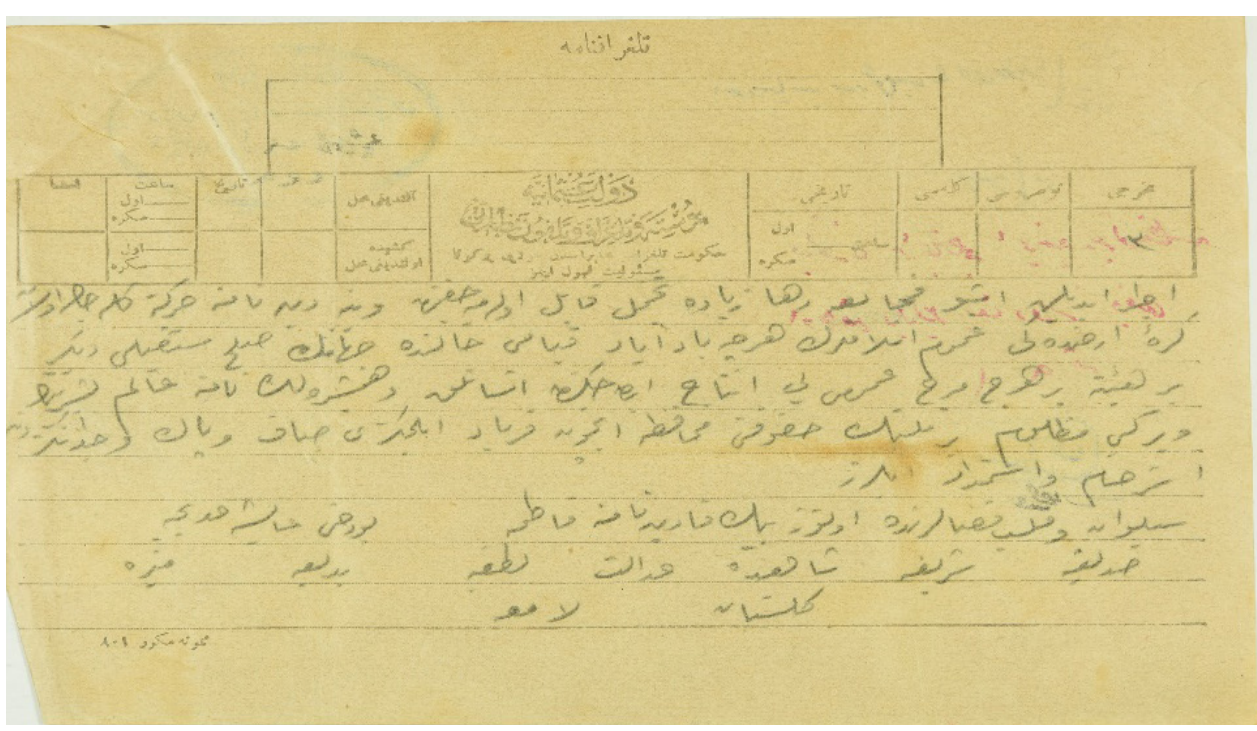

Kaynak: BOA, HR:SYS, 3552-5. 
Ek 3: Muğlalı kadınlar tarafından bir miting yapılıp kararlar alındığına dair yazı.

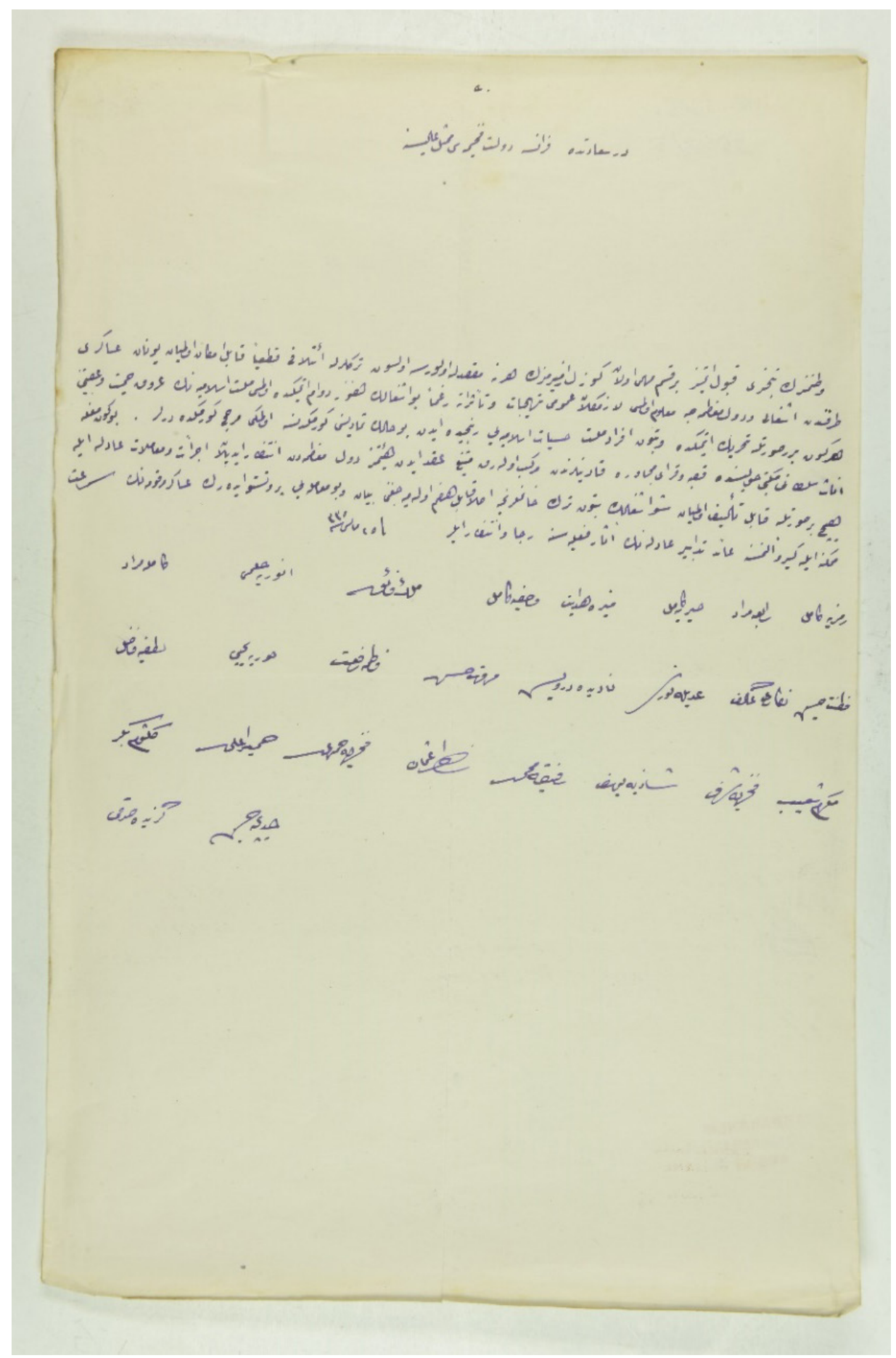

Kaynak: BOA; HR.SYS, 2552-5 